\title{
Electrophysiological Remodeling in Heart Failure
}

\author{
Yanggan Wang, MD, $\mathrm{PhD}^{1}$ and Joseph A. Hill, MD, $\mathrm{PhD}^{2,3}$ \\ ${ }^{1}$ Department of Pediatrics, Emory University, Atlanta, Georgia \\ ${ }^{2}$ Department of Internal Medicine (Cardiology), University of Texas Southwestern Medical Center, \\ Dallas, Texas \\ ${ }^{3}$ Department of Molecular Biology, University of Texas Southwestern Medical Center, Dallas, Texas
}

\begin{abstract}
Heart failure affects nearly 6 million Americans, with a half-million new cases emerging each year. Whereas up to $50 \%$ of heart failure patients die of arrhythmia, the diverse mechanisms underlying heart failure-associated arrhythmia are poorly understood. As a consequence, effectiveness of antiarrhythmic pharmacotherapy remains elusive. Here, we review recent advances in our understanding of heart failure-associated molecular events impacting the electrical function of the myocardium. We approach this from an anatomical standpoint, summarizing recent insights gleaned from pre-clinical models and discussing their relevance to human heart failure.
\end{abstract}

\section{Introduction}

Heart failure is approaching epidemic proportions in industrialized societies[1]. Mortality in this syndrome, which derives from a host of disease-associated insults to the heart, is high, as much as $50 \%$ per year in advanced disease. A prominent mechanism of death in patients with heart failure is arrhythmia, especially tachyarrhythmia, where electrical activation of the heart occurs so rapidly that effective filling and pumping of blood cannot occur. To combat these arrhythmias, implantable devices (ICDs, implantable cardiodefibrillators) have emerged as an important therapeutic strategy designed to abort malignant arrhythmia and restore normal, sinus rhythm.

In parallel with the emergence of ICD therapy, the prominence of anti-arrhythmic drug therapy has declined. The reasons for this decline are several, but stem largely from inefficacy of existing antiarrhythmic pharmacotherapy in patients with structural heart disease. This deficiency, in turn, likely derives from inadequate understanding of fundamental mechanisms of arrhythmogenesis in the large number of disease states which culminate in heart failure.

(C) 2010 Elsevier Ltd. All rights reserved.

Addresses for correspondence: Joseph A. Hill, MD, PhD Division of Cardiology UT Southwestern Medical Center NB11.200 6000 Harry Hines Blvd Dallas, TX 75390-8573 Tel: 214.648.1400 Fax: 214.648.1450 joseph.hill@utsouthwestern.edu. Yanggan Wang, MD, PhD Division of Cardiology Department of Pediatrics Emory University Atlanta, GA 30322 Tel: 404.727.2592

yanggan.wang@emory.edu.

Publisher's Disclaimer: This is a PDF file of an unedited manuscript that has been accepted for publication. As a service to our customers we are providing this early version of the manuscript. The manuscript will undergo copyediting, typesetting, and review of the resulting proof before it is published in its final citable form. Please note that during the production process errors may be discovered which could affect the content, and all legal disclaimers that apply to the journal pertain.

Conflicts of Interest Disclosures

None 
A great deal of work is underway to decipher mechanisms of pathological remodeling of the ventricle[2]. Of necessity, the majority of this mechanistic work is conducted in preclinical models, both in vitro and in vivo. This fact, then, raises an important question: how relevant to clinical arrhythmias in humans are insights gleaned from cell culture or animal models of disease? This question is all the more relevant given that the fundamental electrophysiological anatomy of cardiac myocytes differs among mammals, from mouse to humans; differences in the electrical properties of cardiac myocytes between humans and non-mammalian species are yet more significant. How reliable are insights gleaned from preclinical models in identifying new therapeutic targets in humans? Can we extrapolate discoveries made in nonhuman models of electrical disease to our patients in the clinic? As a step toward addressing these nearintractable questions, we summarize here recent advances in preclinical studies of arrhythmia and discuss relevance to human heart disease. We address this topic from an anatomical standpoint, tracking electrical events as they course through the myocardium, and discussing heart failure-related remodeling events occurring in each tissue. As this field is vast, we do not discuss all of the major channels and transporters; for detailed discussion channels and currents not covered in this review, readers are referred to recent excellent reviews[3-5].

\section{Normal electrical activation of the heart}

Electrical activation of the heart normally commences at the sinoatrial (SA) node, a bundle of specialized cells in the right atrium that fire action potentials spontaneously and automatically (Figure 1). Signals arising in the SA node spread across the right and left atria, stimulating them to contract. Excitation ultimately travels to the atrioventricular (AV) node, a bundle of specialized cells between the atria and ventricles serving as an "electrical bridge" between these two tissues. After a delay, the electrical signal emerges on the ventricular side of the AV node and is conducted through specialized electrical cables (His bundle and Purkinje fibers) to rapidly spread across the endocardial surfaces of both ventricles. Just beyond the bundle of His, the cable splits into two branches, the left bundle branch and the right bundle branch. The left bundle branch is short, dividing into the left anterior fascicle and the left posterior fascicle. The left posterior fascicle is broad and fan-shaped with dual blood supply, making it relatively resistant to ischemic damage. Electrical excitation then enters the contractile myocardium, a functional syncytium where each cell is electrically coupled to its neighbors via gap junctions. As a result, electrical impulses propagate freely between cells in every direction, so that the myocardium functions as a single contractile unit. As electrical activation spreads rapidly across the endocardial surfaces of both ventricles via the His-Purkinje system, mechanical contraction occurs synchronously and efficiently.

Throughout the myocardium, electrically activated cells return to their basal, resting state as their action potentials repolarize. In fact, resetting of electrical excitability in heart tracks the course of excitation with variable delay. One major exception to this rule occurs in the ventricle, where repolarization occurs first in the outer, sub-epicardial zone, even though these cells are the last to be excited. Disorders in the temporal and spatial patterns of repolarization are a major mechanism underlying heart failure-associated ventricular arrhythmias.

\section{Heart failure-related electrophysiological remodeling}

\section{Nodal cells and specialized conduction system}

- SA node-The SA node is a compact region within the right atrium located at the base of the superior vena cava[6,7]. In the absence of extrinsic neural and hormonal control, cells in the SA node will naturally generate action potentials at a rate of approximately 100 times/ minute. Rhythms driven by SA node pacemaker activity ("normal sinus rhythm") occur at $60-100$ beats per minute. 
Within the SA node, a pacemaker current $\left(\mathrm{I}_{\mathrm{f}}\right)$ generates spontaneous depolarization during diastole and consequent spontaneous pacemaker activity[8,9]. The resulting electrical activity in several thousand cells is integrated via tight cell-cell coupling leading to nearly synchronous firing of action potentials[10]. Within the SA node, $\mathrm{I}_{\mathrm{f}}$ manifests morphology-dependent variation, with a smaller $\mathrm{I}_{\mathrm{f}}$ in spindle-like cells as compared with spider-like cells[11]. Cell size-dependent variation has been described[7], as well as age-related variation, with smaller $\mathrm{I}_{\mathrm{f}}$ in adult compared with newborn heart[12]. It is estimated that only about $1 \%$ of the cells in the SA node ("P" cells localized to the center of the node) actually function as leading pacemaker cells[13]. Outside the center of the node, there is a gradual transition in cell type over several millimeters reaching the periphery of the node. Perinodal cells, also called transitional (T) cells, transmit the electrical impulse from the SA node to the right atrium. SA nodal dysfunction may result from abnormalities in either impulse generation by the $\mathrm{P}$ cells or in conduction across the $\mathrm{T}$ cells.

In SA node, the major currents generating phase 0 upstroke of the action potential are the Ltype $\mathrm{Ca}^{2+}$ current, $\mathrm{I}_{\mathrm{Ca}}$, and sodium current, $\mathrm{I}_{\mathrm{Na}} \cdot \mathrm{I}_{\mathrm{Na}}$ is responsible for the action potential upstroke in SA node periphery cells, whereas $\mathrm{I}_{\mathrm{Ca}}$ is responsible in the central cells[7]. In addition to generating the rapid upstroke, $\mathrm{I}_{\mathrm{Ca}}$ is an important contributor to late stage phase 3 pacemaker depolarization. Thus, $\mathrm{I}_{\mathrm{Ca}}$ appears to be important in determining both the action potential waveform and the slope of pacemaker depolarization[14].

Another distinct $\mathrm{Ca}^{2+}$ current present in mammalian SA node is the transient $\mathrm{Ca}^{2+}$ current, i.e. T-type $\mathrm{Ca}^{2+}$ current. Its basic properties include a more negative threshold potential than $\mathrm{I}_{\mathrm{Ca}}$ and a more rapid rate of inactivation[15]. Although its amplitude is much smaller than $\mathrm{I}_{\mathrm{Ca}}$, its activation threshold lies near diastolic potentials and thus has been hypothesized to contribute to pacemaker activity[16]. Consistent with this, Hagiwara et al. have shown in rabbit SA node cells that abolishing T-type $\mathrm{Ca}^{2+}$ current with $\mathrm{Ni}^{2+}$ leads to a $14 \%$ increase in cycle length[15]. We now know that there are three T-type channel isoforms $\mathrm{Ca}_{\mathrm{V}} 3.1-3.3\left(\alpha_{1 \mathrm{G}}\right.$, $\alpha_{1 \mathrm{H}}$ and $\left.\alpha_{1 \mathrm{I}}\right)$, two of which $\left(\mathrm{Ca}_{\mathrm{V}} 3.1\right.$ and $\left.\mathrm{Ca}_{\mathrm{V}} 3.2\right)$ are expressed in the heart[17]. In contrast with $\mathrm{Ca}^{2+}$ current, $\mathrm{I}_{\mathrm{Na}}$ has a negligible effect on $\mathrm{SA}$ node cycle length[14].

Abnormalities in sinoatrial node function are seen frequently in clinical and experimental heart failure[18,19]. For example, patients with heart failure can present with bradycardia[20], and animal studies have pointed to increases in the intrinsic cycle length of the SA node with an amplified response to acetylcholine as a contributing mechanism[18,21]. In a rabbit model of combined volume and pressure overload-induced heart failure, $\mathrm{I}_{\mathrm{f}}$ was reduced significantly, accompanied by a decrease in the slow component of the delayed rectifier current $\left(\mathrm{I}_{\mathrm{Ks}}\right)$. By contrast, T-type and L-type $\mathrm{Ca}^{2+}$ current, rapid and ultrarapid delayed rectifier $\mathrm{K}^{+}$current ( $\left.\mathrm{I}_{\mathrm{Kur}}\right)$, transient outward $\mathrm{K}^{+}$current $\left(\mathrm{I}_{\mathrm{to}}\right)$, and sodium-calcium exchange current $\left(\mathrm{I}_{\mathrm{NCX}}\right)$ are unaltered[22], and HF-associated decreases in heart rate were attributed to remodeling of $\mathrm{I}_{\mathrm{f}}$. In addition to chronic reduction in heart rate[23], SA nodal function is altered in patients with persistent atrial fibrillation (AF)[24], a condition commonly seen in heart failure. Indeed, even transient episodes of atrial tachyarrhythmias[25] which occur commonly in heart failure, induce significant electrical remodeling in the SA node and consequent nodal dysfunction.

At a molecular level, chronic reductions in heart rate, as can be seen in heart failure, lead to declines in the transcript abundance of several ion channel subunits, including the voltagegated $\mathrm{Na}^{+}$channel $\beta$-subunit Nav $\beta 1$ (-25\%), T-type $\mathrm{Ca}^{2+}$ channel subunit Cav3.1 (-29\%), $\mathrm{K}^{+}$-ATP channel $\alpha$-subunits Kir6.1 (-28\%), and $\mathrm{K}^{+}$channel regulatory $\beta$-subunits $\mathrm{Kv} \beta 2(-41 \%)$ and $\mathrm{Kv} \beta 3(-30 \%)[23]$. By contrast, some ion channel genes are up-regulated, including $\mathrm{K}^{+}$ channel $\alpha$-subunits (Kv1.1, $+30 \%$; Kir2.1, $+29 \%$; Kir3.1, $+41 \%)$, hyperpolarization-activated cation channels (HCN2, $+24 \%$; HCN4, $+52 \%)$, and the gap junction channel connexin 43 $(+26 \%)[23]$. Down-regulation of HCN4 and HCN2 expression, however, was also reported in 
sinus node of canine ventricular tachypacing-induced HF[26]. Short bursts of rapid atrial pacing (10-15 minutes), simulating transient atrial tachyarrhythmias, alter sinus node function in humans, leading to increases in both sinoatrial conduction time (SACT) and corrected sinus node recovery time (CS-NRT) [25]. After electrical cardioversion of longstanding (>3 months) AF, CS-NRT was found to remain significantly increased, whereas impairments of sinus node automaticity were reversible[27].

- AV node-The atrioventricular (AV) node is an electrical relay station connecting the atria and ventricles. Conduction through the AV node is slow, affording a time delay that allows the ventricles to fill with blood that was mechanically pumped during atrial systole. The AV junctional tissue has its own intrinsic pacemaker activity at 40-60 beats per minute, such that the AV node can assume the role of cardiac pacemaker in the setting of SA node dysfunction. By virtue of the fact that the AV node transmits electrical impulses slowly, it limits the number of impulses conducted from the atria to the ventricles. This function is important during fast atrial rates (e.g. atrial flutter or fibrillation) where only a fraction of impulses are successfully conducted to the ventricles and mechanical performance of the ventricles is thereby preserved.

The AV node and perinodal area comprises at least three electrophysiologically distinct cell types: the atrionodal $(\mathrm{AN})$, the nodal $(\mathrm{N})$, and the nodal-His $(\mathrm{NH})$ cells. In the $\mathrm{N}$ cells, an inward calcium channel current $\left(\mathrm{I}_{\mathrm{Ca}}\right)$ is the basis of the action potential upstroke[28], whereas the upstroke of the action potential in AN and $\mathrm{NH}$ cells depends mainly on an inward sodium current $\left(\mathrm{I}_{\mathrm{Na}}\right)$. Because $\mathrm{I}_{\mathrm{Na}}$ in AN and NH cells is larger and has more rapid kinetics than $\mathrm{I}_{\mathrm{Ca}}$ in $\mathrm{N}$ cells, conduction is faster through atrial transitional and $\mathrm{NH}$ regions than through the core of the AV node. Fast pathway conduction through the AV node bypasses many of the $\mathrm{N}$ cells by traversing transitional cells, whereas slow pathway conduction passes through the entire compact AV node[29].

Adrenergic activation is a hallmark feature of heart failure[30]. In the AV node, sympathetic nerve activation accelerates pacemaker function (due to increases in $\mathrm{I}_{\mathrm{Ca}}$ ), enhances excitability, heightens action potential amplitude, increases conduction velocity, and decreases the effective refractory period of AV nodal cells, which together facilitate both antegrade slow conduction and retrograde fast conduction through the AV node[31]. In failing human ventricle, adrenergic over-activation is accompanied by down-regulation of $\beta 1$-adrenergic receptors with preservation of $\beta 2$-adrenoceptors, which shifts the $\beta 1$ : $\beta 2$ ratio towards the $\beta 2$-subtype. And the resulting relative over-activation of $\beta 2$-subtype receptors may play opposing roles in the failing heart, viz. maintaining cardiac contractility via activation of $\mathrm{G}_{\mathrm{s}}$ with consequent increases in cAMP formation, or inhibition of contractility via enhanced coupling to $G_{i}$ and thus decreased adenylyl cyclase activity[21,32]. Whether a shift of the $\beta 1: \beta 2$ ratio also occurs in AV node in the setting of heart failure is not known.

Although $\beta$-adrenergic antagonists are effective in regulating AV nodal conduction in many patients, enhanced nodal conduction remains a significant issue in patients with atrial fibrillation and heart failure. In addition to the PKA/cAMP pathway, recent studies suggest that CaMKII, an enzyme which is significantly activated in heart failure, may play an important role in regulating heart rate and electrical conductivity. Khoo el al. reported that in a model of genetic CaMKII inhibition by cardiac-specific expression of autocamtide 3 inhibitory peptide (AC3-I), PR and AH intervals were significantly prolonged, manifesting enhanced

Wenckebach-type conduction block[33]. CaMKII activity has also been implicated in electrical activity within the $\mathrm{SA}$ node via regulation of $\mathrm{I}_{\mathrm{Ca}}[34]$ and $\mathrm{I}_{\mathrm{f}}[35]$. In line with these findings, our recent studies of CaMKII $\delta$ knockout mice reveal heart rate declines in the setting of $\beta$ adrenergic stimulation or increased workload (unpublished results). Further, Wu et al. demonstrated that adrenergic regulation of heart rate depends on CaMKII-mediated regulation of SA nodal $\mathrm{Ca}^{2+}$ homeostasis; CaMKII inhibition had no effect on the isoproterenol response 
in SA nodal cells when $\mathrm{SR} \mathrm{Ca}^{2+}$ release was disabled, and CaMKII inhibition was only effective at slowing heart rates during $\beta$-adrenergic stimulation[36]. Together, these observations raise important questions regarding whether CaMKII activity plays a role in failure-related alterations in heart rate and electrical conduction and highlight yet further the prospect of CaMKII as a therapeutic target in heart disease.

- Purkinje cells-In 1839, Jan Evangelista Purkinje described a network of fibers located on the endocardial surface of the left and right ventricles[37]. These fibers are specialized cables that conduct electrical impulses rapidly over the endocardial surface, thereby enabling coordinated mechanical activation of both ventricles. Purkinje myocytes have a higher density of sodium channels and mitochondria, and they contain fewer myofibrils than surrounding contractile myocardium. Transmission of electrical impulses to ventricular myocytes occurs by cell-to-cell communication via gap junctions. The Purkinje conducting system is capable of intrinsic pacemaker activity at a rate of 30-40 impulses per minute. If the SA and AV nodes are injured, the ventricular Purkinje conducting system can assume control of heart rate and rhythm.

Cardiac Purkinje cells play an important role in the generation of ventricular arrhythmias, particularly those related to triggered activity[38,39]. In regions of myocardial infarction, ionic currents are significantly altered in subendocardial Purkinje cells[40-42]. In heart failure, the risk of drug-induced torsades de pointes is increased significantly, a phenomenon which is associated with the remodeling of ionic currents in cardiac Purkinje cells[43]. In rapid pacinginduced heart failure, $\mathrm{I}_{\text {to }}$ density in Purkinje cells is reduced without change in its voltage dependence or kinetics[44]. Heart failure is also associated with reduced inward-rectifier current density without changes in current-voltage relationship. In heart failure, densities of $\mathrm{L}-$ and T-type calcium currents, rapid and slow delayed rectifier $\mathrm{K}^{+}$currents, and $\mathrm{Na}^{+}-\mathrm{Ca}^{2+}$ exchange currents are typically unaltered, but inactivation of $\mathrm{I}_{\mathrm{Ca}, \mathrm{L}}$ is slowed at positive potentials. Purkinje fiber action potentials from heart failure dogs manifest decreased phase 1 amplitudes and elevated plateau voltages, and they demonstrate twice as much prolongation on exposure to the rapid delayed rectifier $\mathrm{K}^{+}$channel blocker E-4031 as control Purkinje fibers [44]. Down-regulation of $\mathrm{I}_{\mathrm{to}}$, along with slowed inactivation of $\mathrm{I}_{\mathrm{Ca}, \mathrm{L}}$, is likely responsible for the positive shift in the plateau voltage of cardiac Purkinje cells. Together, these heart failureinduced ion channel changes in cardiac Purkinje cells may promote arrhythmogenic afterdepolarizations. In fact, slowed $\mathrm{I}_{\mathrm{Ca}, \mathrm{L}}$ inactivation would be expected to promote $\mathrm{I}_{\mathrm{Ca}, \mathrm{L}^{-}}$ dependent early afterdepolarizations under conditions of delayed repolarization.

\section{Contractile myocardium}

- Atrial tissue-Atrial fibrillation (AF), the most common arrhythmia in heart failure, contributes substantially to morbidity and mortality in this syndrome[1]. AF is an independent risk factor for stroke and evidence suggests that atrial fibrillation promotes progression of heart failure[45]. AF tends to be self-maintaining by creating an electrophysiological substrate that facilitates AF, a concept which has been coined as "AF begets AF"[46]. Indeed, remodeling of atrial myocytes is a major contributor to the increased propensity to AF in patients with heart failure[47]. To date, therapy with antiarrhythmic drugs to maintain sinus rhythm has been disappointing, and there is concern that untoward side effects could offset the benefits of sinus rhythm maintenance. Thus, ventricular rate control and anticoagulation are recommended as mainstays of therapy for persistent $\mathrm{AF}[48]$.

In some patients, paroxysmal AF initiates from automatic foci localized within sleeves of musculature extending retrograde into the pulmonary veins. Indeed, catheter-based ablation of $\mathrm{AF}$, often by electrically isolating the pulmonary veins, has emerged as a prominent treatment strategy[49] As a general rule, ablation is more effective for paroxysmal AF than for chronic 
$\mathrm{AF}$ [49], consistent with the concept that AF triggers remodeling events that promote its persistence. Presently, it is believed that changes in atrial electrophysiologic substrate, beyond structural heart disease, contribute to $\mathrm{AF}$ recurrence and/or perpetuation. Thus, a long-term objective of AF therapy is to prevent the initial development of arrhythmia-related ion channel remodeling and tissue fibrosis.

It was well established that atrial remodeling is a complex process that develops over time [4]. The type and extent of remodeling depends on the strength and duration of the stressor. The most common stressors of atrial myocytes are electrical (tachycardia, AF) or mechanical (volume or pressure overload). Some evidence suggests that the ionic remodeling that occurs in tachycardia-dependent disease is distinct from that occurring in heart failure[50,51]

Ionic remodeling occurs early during AF. Loss of heart rate-dependent adaptation of atrial refractoriness, short atrial refractoriness, and AF duration have each been suggested to be a predictor of $\mathrm{AF}$ recurrence[52]. Decreases in $\mathrm{I}_{\mathrm{Ca}}$ contribute to the shortening of the atrial action potential, whereas decreases in $\mathrm{I}_{\text {to }}$ likely contribute to loss of physiological rate adaptation of the action potential[53,54]. These findings from preclinical models have been largely confirmed in humans[55,56]. Ironically, declines in $\mathrm{I}_{\mathrm{Ca}}$ could be viewed as an adaptive alteration that antagonizes rate-induced calcium overload[57]. Reduced $\mathrm{Na}^{+}$current $\left(\mathrm{I}_{\mathrm{Na}}\right)$ density has also been observed in a canine model of atrial fibrillation [58], which may contribute to declines in conduction velocity,

In one report, decreased density of L-type $\mathrm{Ca}^{2+}$ channels was consistently observed following long-term (several weeks) rapid atrial pacing, whereas inward T-type $\mathrm{Ca}^{2+}$ current remained unchanged[53]. This, combined with recent studies demonstrating that $\mathrm{Ca}^{2+}$ influx through Tand L-type channels have different effects on contractility and intracellular signaling [59], suggests that in chronic AF, T-type $\mathrm{Ca}^{2+}$ current may be a significant contributor to intracellular $\mathrm{Ca}^{2+}$ overload. Consistent with this, Lee et al[60] reported that verapamil attenuated shortening of refractoriness after 1-day of pacing but did not alter electrophysiological remodeling long term ( 1 and 6 weeks). Fareh et al[61,62] reported that the T-type $\mathrm{Ca}^{2+}$ channel blocker, mibefradil, is superior to L-type $\mathrm{Ca}^{2+}$ channel blockers in attenuating tachycardia-dependent remodeling. Based on these findings, one could speculate that patients with paroxysmal AF may benefit from $\mathrm{L}$-type $\mathrm{Ca}^{2+}$ blocker therapy, whereas the long-term remodeling which occurs in persistent $\mathrm{AF}$ might respond to T-type $\mathrm{Ca}^{2+}$ channel blockers.

Atrial remodeling in heart failure is difficult to study, owing to complex interplay between diseased tissue and disease-associated neurohumoral activation. In a canine model of pacinginduced heart failure, decreases in $\mathrm{I}_{\mathrm{Ca}, \mathrm{L}}, \mathrm{I}_{\mathrm{to}}$, and $\mathrm{I}_{\mathrm{Ks}}$, and an increase in $\mathrm{I}_{\mathrm{NCX}}$ were observed in atrial myocytes[47]. In atrial myocytes isolated from heart failure patients, by contrast, we have reported that $\mathrm{I}_{\text {to }}$ density is significantly larger with an accelerated time course of recovery [63]. In experimental heart failure, attenuated rate adaptation of atrial refractoriness (long action potential duration at high rates) is observed[53]. Similar findings have been reported in human heart failure[64]. Unlike the "AF begets AF" model, in which a decrease in effective refractory period (ERP) is critical to the development of sustained AF, in atrial myocytes of failing human heart, no difference or even an increase in ERP has been observed[65], and there is no significant change in action potential duration[63].

These differences may result from different remodeling mechanisms occurring between atrial tachycardia/AF and heart failure. For example, Yue et al reported that in a canine model, heart failure decreased both $\mathrm{I}_{\mathrm{Ks}}$ and $\mathrm{I}_{\mathrm{Ca}, \mathrm{L}}$ by about $30 \%$, whereas atrial tachycardia decreased $\mathrm{I}_{\mathrm{Ca}, \mathrm{L}}$ by $70 \%$ without affecting $\mathrm{I}_{\mathrm{K}}[53]$. Animal studies also suggest that electrical remodeling is reversible in both atrial tachycardia/AF and heart failure when the stressor is removed[66]. However, in both atrial tachycardia-dependent or in heart failure-dependent remodeling, 
irreversible changes can occur. For example, evidence suggests that aspects of structural remodeling, including interstitial fibrosis, cellular hypertrophy, and degeneration which develop concurrently with electrical alterations can be irreversible[66]. Fibrosis has been detected in the atria of patients with heart failure due to prior myocardial infarction or idiopathic heart failure[67-69] and in an animal model of ventricular pacing-induced HF[70]. Together, these irreversible changes may contribute to reduced efficacy of medical therapy for chronic $\mathrm{AF}$ in patients with heart failure.

- Ventricular tissue-Relative to atrial myocytes, electrical remodeling in failing ventricular myocytes has been intensively studied, and several excellent reviews are available $[3-5,71,72]$. Here, we focus on recent progress in a limited number of areas.

Cellular remodeling: Prolongation of the ventricular action potential is a hallmark of heart failure. Although many discrepancies exist regarding the specific ionic and molecular processes occurring in heart failure, studies in animal models and in humans with heart failure have consistently revealed action potential duration (APD) prolongation due to functional down-regulation of outward potassium currents[73,74], functional up-regulation of inward calcium current and changes in $\mathrm{Ca}^{2+}$ current inactivation[75-77], or increases in late sodium currents[78]. APD prolongation may prolong calcium channel opening and thereby contribute to preservation of contractile force. However, it also increases the risk of $\mathrm{Ca}^{2+}$ overload which could contribute to abnormal triggered impulses and perturbed signaling events.

Although all myocardial cell layers exhibit significant APD prolongation in heart failure, such prolongation is typically heterogeneous. In a mouse model of pressure-overload heart failure, we found that APD was more prolonged in subepicardial myocytes than in subendocardial myocytes due to the more significant reduction of outward potassium currents[79]. In a canine model of rapid ventricular pacing-induced heart failure, APD prolongation of midmyocardial (M) cells was substantially greater than epicardial cells, eliciting a significant increase in the transmural APD gradient and consequent increases in the transmural dispersion of repolarization[80]. The magnitude of APD prolongation in M cells was found to be similar to QT interval prolongation, suggesting that it may contribute to QT interval changes observed in heart failure[80]. However, another study showed that, even though APD was increased, transmural dispersion of APD was diminished in pacing-induced heart failure relative to that seen in controls [81]. Although changes in transmural APD vary across species, leading to either an increase or a decrease in transmural dispersion, the heterogeneous and selective prolongation of repolarization between cell types across the ventricular wall underlies an electrophysiological mechanism for unidirectional block, reentry, and arrhythmogenicity.

\section{- Ionic mechanisms underlying ventricular electrical remodeling}

1) Sodium current: The cardiac voltage-dependent $\mathrm{Na}$ channel (SCN5A or NaV1.5) generates a large inward current $\left(\mathrm{I}_{\mathrm{Na}}\right)$ within the first millisecond of excitation and thereby mediates rapid membrane depolarization (the upstroke of the cardiomyocyte action potential). As a result, it is a major determinant of conduction velocity in the atria and ventricles. Inactivation of $\mathrm{I}_{\mathrm{Na}}$ has both fast (fast inactivation, which lasts several milliseconds) and slow (which can last hundreds of milliseconds) components[82]. The current associated with the slow inactivating phase has been referred to as late, sustained, or persistent $\mathrm{I}_{\mathrm{Na}}\left(\mathrm{I}_{\mathrm{Na}, \mathrm{L}}, \mathrm{I}_{\mathrm{Na} \text {,sus }}\right.$, $\mathrm{I}_{\mathrm{Na}, \mathrm{p}}$ ) to distinguish it from the peak transient $\mathrm{I}_{\mathrm{Na}}$. Some evidence suggests $\mathrm{I}_{\mathrm{Na}, \mathrm{L}}$ arises from a fraction of the $\mathrm{Na}^{+}$channels that intermittently lose their inactivation[83], as opposed to a distinct set of channel molecules.

The amplitude of late $\mathrm{I}_{\mathrm{Na}}$ is less than $1 \%$ that of peak $\mathrm{I}_{\mathrm{Na}}$, but it is sufficient to prolong action potential duration[84]. In animal models of heart failure, peak $\mathrm{I}_{\mathrm{Na}}$ has been reported to be 
decreased[85], unchanged [73], or increased[78,86,87]. Also, peak $\mathrm{I}_{\mathrm{Na}}$ has been reported to be increased in human heart failure[88]. Maltsev et al[89] reported that late $\mathrm{I}_{\mathrm{Na}}$ is present in ventricular myocytes from normal human mid-myocardium and from failing human hearts, contributing to $15-20 \%$ of APD in both species. Whereas peak $\mathrm{I}_{\mathrm{Na}}$ density is often decreased in heart failure, $\mathrm{I}_{\mathrm{Na}, \mathrm{L}}$ as a percentage of peak $\mathrm{I}_{\mathrm{Na}}$ can be significantly increased in both conditions (7-12-fold increase)[90]. Coincident with the increased density, $\mathrm{I}_{\mathrm{Na}, \mathrm{L}}$ decay was found to be slower in failing dog and human hearts[88]. Given this, increased $\mathrm{I}_{\mathrm{Na}, \mathrm{L}}$ likely plays an important role in APD prolongation in heart failure and may contribute to arrhythmogenesis. $\mathrm{I}_{\mathrm{Na}, \mathrm{L}}$ inhibition decreased beat-to-beat AP variability and eliminated early afterdepolarizations in failing cardiomyocytes[88]. Whether the changes in $\mathrm{I}_{\mathrm{Na}}$ manifest transmural variations in the failing ventricle or contribute to changes in transmural dispersion is unknown.

2) Potassium currents: $\mathrm{K}^{+}$channels are critical to the restoration of cardiac excitability, because they play a fundamental role in repolarization of the action potential. Over 50 genes encoding $\mathrm{K}^{+}$channel subunits have been cloned in man, and many aspects of their biophysical properties, channel assembly and stoichiometry, and functional modulation by second messengers and ligands have been elucidated. Numerous studies have linked $\mathrm{K}^{+}$channel gene mutations with a variety of diseases, and therapeutic approaches to target these channels have been formulated[91,92]. Here we will focus on a limited set of $\mathrm{K}^{+}$currents which play a major role in myocyte repolarization.

Transient outward current $\left(\mathrm{I}_{\text {to }}\right)$ : Prominent transient outward $\mathrm{K}^{+}$current $\left(\mathrm{I}_{\mathrm{to}}\right)$ has been recorded in ventricular myocytes isolated from the hearts of many species, including mice, rats, rabbits, cows, cats, dogs, ferrets and humans [93]. Depending on species and regions within the heart, there are at least two distinct $\mathrm{I}_{\text {to }}$ phenotypes that can be distinguished based on their molecular, biophysical and pharmacological properties: $\mathrm{I}_{\mathrm{to}, \mathrm{f}}$ which is characterized by fast recovery from inactivation, and $\mathrm{I}_{\mathrm{to}, \mathrm{s}}$ which is characterized by slow recovery from inactivation. $\mathrm{I}_{\text {to, }}$ is mediated by Kv4.2 and/or Kv4.3 channels, whereas $\mathrm{I}_{\mathrm{to}, \mathrm{s}}$ is mediated by Kv1.4 channels. Their relative contributions to $\mathrm{I}_{\text {to }}$ vary between species and across regions of the heart[94]. Across the left ventricular free wall, a gradient of the two distinct $\mathrm{I}_{\text {to }}$ phenotypes and a gradient in peak current density of a single $\mathrm{I}_{\text {to }}$ phenotype are each present in many species, including humans.

Kv1.4, Kv4.3, and KChIP2 mRNAs are expressed in the human LV[95,96], and based on the gradients of protein expression, both KChIP2 and $\mathrm{Kv} 4.3$ are thought to contribute to $\mathrm{I}_{\mathrm{to}, \mathrm{f}}$ [97]. However, only reductions in $\mathrm{Kv} 4.2$ and $\mathrm{Kv} 4.3$ abundances have been linked consistently to the diminished $\mathrm{I}_{\mathrm{to}}$ densities typically seen in cardiac hypertrophy[98].

$\mathrm{I}_{\mathrm{to}}$, a major determinant of the early phase of AP repolarization, plays a crucial role in modulating AP plateau and repolarization profiles. In fact, down-regulation in $\mathrm{I}_{\text {to }}$ contributes to changes in AP morphology observed in many forms of heart disease[53,99-101]. Studies designed to determine the contribution of $\mathrm{I}_{\mathrm{to}}$ to AP duration, however, have produced conflicting results. In ventricular myocytes from failing heart, $\mathrm{I}_{\text {to }}$ was observed to be reduced and was postulated to promote prolongation of APD[73,102]. However, inhibition of $\mathrm{I}_{\mathrm{to}}$ by 4aminopyridine (4-AP) in the absence of pipette $\mathrm{Ca}^{2+}$ buffers shortens APD in ventricular myocytes[103,104]. Yue et al[53] reported that suppression of $I_{t o}$ could either prolong or shorten APD in canine atrial myocytes, depending on the density of $\mathrm{I}_{\mathrm{Ca}, \mathrm{L}}$. We have reported that increased $\mathrm{I}_{\mathrm{to}}$ in atrial myocytes from patients with heart failure did not alter APD[63]. One potential explanation for these inconsistencies is that in many common diseases, such as heart failure, myocardial infarction, and atrial fibrillation, down-regulation of $\mathrm{I}_{\mathrm{to}}$ is accompanied by alterations in $\mathrm{I}_{\mathrm{Ca}, \mathrm{L}}$. The complex interplay among these current alterations results in changes in plateau level, which, in turn, induces secondary changes in activity of the L-type calcium 
channel, $\mathrm{Na}^{+} / \mathrm{Ca}^{2+}$ exchangers, and other currents[105-107]. In aggregate, these complex changes make alterations in APD difficult to predict.

Although $\mathrm{I}_{\mathrm{to}}$ is prominent in human heart, its role in ventricular APD is limited due to the presence of large, delayed rectifier currents. It is clear, however, that reduction in $\mathrm{I}_{\mathrm{to}}$ will slow the early phase of AP repolarization (generally characterized by $\mathrm{APD}_{30}$, the duration of time for the action potential to reach $30 \%$ repolarization). The slowed early repolarization is critical to the success of AP conduction in cardiac tissue. We first reported the crucial role of $\mathrm{I}_{\mathrm{to}}$ in facilitation and maintenance of AP propagation at fast heart rates in rabbit atrial myocytes [108]. In these experiments, inhibition of $\mathrm{I}_{\text {to }}$ by fast pacing delayed early repolarization and increased $\mathrm{APD}_{30}$. This lengthening of $\mathrm{APD}_{30}$ allows the proximal ("leader") cell to provide more coupling current to the distal ("follower") cell to bring it to its excitation threshold, thereby facilitating AP propagation. In the normal LV, $\mathrm{I}_{\mathrm{to}}$ density is larger in subepicardial myocytes than in subendocardial myocytes. This transmural gradient of $\mathrm{I}_{\mathrm{to}}$ contributes to the transmural gradient of $\mathrm{APD}_{30}$, which enables subendocardial myocytes to provide more coupling current to depolarize adjacent cells. As such, conduction of excitability is facilitated in the physiological direction of endocardium to epicardium but disfavored in the opposite direction (Figure 2). In heart failure, however, this directional preference of conduction is blunted due to disease-related declines in the transmural gradient of $\mathrm{I}_{\mathrm{to}}[79]$. Together, these changes may be arrhythmogenic, as conduction of abnormal impulses originating in the subepicardium is relatively facilitated. Consistent with this, epicardial-site pacing is associated with VT in patients with heart failure[109,110]

Delayed rectifier $\boldsymbol{K}^{+}$current $\left(I_{K}\right)$ : Delayed rectifier $\mathrm{K}^{+}$current $\left(\mathrm{I}_{\mathrm{K}}\right)$ has different functional components depending on the species. In human heart, $I_{\mathrm{K}}$ can be separated into ultrarapid $\left(I_{\mathrm{Kur}}\right)$, rapid $\left(I_{\mathrm{Kr}}\right)$ and slow $\left(I_{\mathrm{Ks}}\right)$ components. These currents exhibit different kinetics and pharmacological properties, are regulated by different intracellular signaling pathways, and are encoded by separate genes (hKv1.5, hERG, and KCNQ1/KCNE1, respectively)[111]. The delayed rectifier current is primarily responsible for initiating phase 3 repolarization, thereby governing action potential duration and tissue refractoriness.

Defects in $\mathrm{I}_{\mathrm{K}}$ underlie certain forms of the hereditary long QT syndrome[112]. A number of $\mathrm{I}_{\mathrm{Kr}}$-blocking drugs can induce excessive action potential prolongation and cause acquired long QT syndrome with consequent increased risk of sudden death[113]. At fast heart rates, $\mathrm{I}_{\mathrm{Kr}}$ contributes less to repolarization than $\mathrm{I}_{\mathrm{Ks}}[114]$ leading to reverse use-dependence of $\mathrm{I}_{\mathrm{Kr}}$ blockers, i.e. these agents manifest their greatest effects on APD at slow heart rates. In contrast, $\mathrm{I}_{\mathrm{Ks}}$ blockers might be expected to exert their greatest effects on APD at relatively fast rates, with a reduced propensity for pro-arrhythmia at slow rates. However, some recent studies suggest that $\mathrm{I}_{\mathrm{Ks}}$ plays only a limited role in action potential repolarization. For example, blocking $\mathrm{I}_{\mathrm{Ks}}$ results in little or no prolongation of APD in normal ventricle, regardless of pacing frequency[115]. Furthermore, $\mathrm{I}_{\mathrm{Ks}}$ contributes to repolarization only when the action potential is abnormally prolonged[116]. Thus, $\mathrm{I}_{\mathrm{Ks}}$ serves predominantly to prevent excessive APD prolongation, and blocking $\mathrm{I}_{\mathrm{Ks}}$ may remove this "safety mechanism" and thereby contribute to triggered arrhythmias.

Relative to $\mathrm{I}_{\mathrm{to}}$, less is known about delayed rectifier $\mathrm{K}^{+}$currents in heart failure. Delayed rectifier $\mathrm{K}^{+}$currents are reduced in ventricular myocytes from pacing-induced heart failure [117] and in models of cardiac hypertrophy[118-121]. However, other studies have reported no changes in delayed rectifier $\mathrm{K}^{+}$current in cardiac hypertrophy[122-124]. In a rapid-pacinginduced $\mathrm{HF}$ model in rabbits, $\mathrm{I}_{\mathrm{Ks}}$ was reduced, but $\mathrm{I}_{\mathrm{Kr}}$ was unchanged[125]. In failing human ventricular myocytes, the delayed rectifier current has been reported to be small and unchanged [99]. 
ATP-sensitive potassium channels ( $\mathrm{K}^{+}$-ATP channels): $\mathrm{K}^{+}$-ATP channels play important roles in many cellular functions by coupling cell metabolism to electrical activity. Detected at high density first in cardiac sarcolemma[126], the $\mathrm{K}^{+}$-ATP channel is an octamer composed of four Kir6 subunits and 4 sulfonylurea receptor (SUR) subunits. The Kir6 subunits regulate the inwardly rectifying potassium channel pore, whereas the SUR subunits, ATP-binding cassette proteins, serve a regulatory role, modulating channel activity based on cellular ATP levels[127-129]. Heterologous reconstitution experiments have suggested that the cardiac $\mathrm{K}^{+}$-ATP channel comprises heteromultimerized Kir6.2 and SUR2A subunits[130].

Adenosine triphosphate (ATP) and nucleotide diphosphates (NDPs) are the major regulators for $\mathrm{K}^{+}$-ATP channel activity[131]. ATP inhibits channel activity, and MgADP induces channel opening[132]. In response to metabolic injury with associated declines in ATP and increases in MgADP, $\mathrm{K}^{+}$-ATP channels open, reducing cell excitability and protecting the tissue from damage. This occurs by a reduction in action potential duration, which leads to decreased inward $\mathrm{Ca}^{2+}$ flux, diminished contraction, and conservation of cellular energy stores.

In HF, poorly defined pathological events lead to disruption of the communication between cellular energetic signals and $\mathrm{K}^{+}$-ATP channel function. This breakdown in intracellular signaling results in an inability of the $\mathrm{K}^{+}$-ATP channel complex to appropriately recognize cellular metabolic stress and consequent failure to carry out its homeostatic functions[133]. Cardiomyocytes isolated from mice with heart failure fail to demonstrate either $\mathrm{K}^{+}$-ATP channel activation in response to cellular metabolic stress or hypoxia-induced shortening of the action potential[133]. Thus, heart failure-related dysregulation of $\mathrm{K}^{+}$-ATP channels appears to contribute to the overall pathogenesis of the syndrome.

Because of the heterogeneous effect of APD shortening in the epicardium versus endocardium, and in ischemic versus non-ischemic areas, concerns have been raised that potassium channel activation may further increase dispersion of refractoriness and promote arrhythmias.

However, clinical trials have not uncovered increases in life-threatening arrhythmias for any of the $\mathrm{K}^{+}$-ATP channel openers[134]. Instead, some clinical studies even reported decreased incidence of malignant ventricular arrhythmias in subjects exposed to $\mathrm{K}^{+}$-ATP channel openers [135].

\section{3) Other currents}

3) Other currents: L-type $\boldsymbol{C a}^{2+}$ current: The L-type $\mathrm{Ca}^{2+}$ current $\left(\mathrm{I}_{\mathrm{Ca}, \mathrm{L}}\right)$ is the primary source of $\mathrm{Ca}^{2+}$ entry in cardiac myocytes, triggering release of $\mathrm{Ca}^{2+}$ from sarcoplasmic reticular stores, activating a number of $\mathrm{Ca}^{2+}$-sensitive signaling cascades, and initiating actin-myosin crossbridge cycling. These channels are comprised of heteromultimers of at least three different subunits $(\alpha 1 \mathrm{c}, \alpha 2 \delta$, and $\beta 2)$. The pore-forming $\alpha 1 \mathrm{c}$ subunit specifies basic channel characteristics, and serves as a docking site for several regulatory molecules including calcineurin; the $\alpha 2 \delta$ and $\beta$ subunits are powerful modulators of channel expression, open probability, activation, and inactivation[136-140]. $\mathrm{I}_{\mathrm{Ca}, \mathrm{L}}$ is expressed differentially across the wall of the ventricle, manifesting a clear transmural gradient of channel density. Transmural variations of $\mathrm{I}_{\mathrm{Ca}, \mathrm{L}}$ have been reported in canine[141], rat[142], and mouse[143] LV, but not in guinea pig ventricle[144].

$\mathrm{I}_{\mathrm{Ca}, \mathrm{L}}$ density is altered in a number of animal models of ventricular hypertrophy and heart failure. Depending on the severity of disease, $\mathrm{I}_{\mathrm{Ca}, \mathrm{L}}$ density has been reported to be increased, decreased, or unchanged. In general, $\mathrm{I}_{\mathrm{Ca}, \mathrm{L}}$ density is increased in mild-moderate hypertrophy and decreased in severe hypertrophy and heart failure[138,139]. The most common change in $\mathrm{I}_{\mathrm{Ca}, \mathrm{L}}$ in heart failure is a slowing of the decay of the whole-cell current[145,146], a change which may contribute to APD prolongation and to elevation of intracellular $\mathrm{Ca}^{2+}$ levels. 
The mechanism underlying the prolonged decay of whole-cell current is multifactorial. Cardiac L-type $\mathrm{Ca}^{2+}$ channels are known to inactivate through voltage- and $\mathrm{Ca}^{2+}$-dependent mechanisms $[147,148]$. Pure voltage-dependent inactivation has a substantially slower time course of development than $\mathrm{Ca}^{2+}$-dependent inactivation and plays a minor role in inhibition of $\mathrm{Ca}^{2+}$ influx into the cell. Thus, the major determinants of the inactivation kinetics of $\mathrm{Ca}^{2+}$ current during depolarization are $\mathrm{Ca}^{2+}$-dependent mechanisms[149]. Furthermore, $\mathrm{Ca}^{2+}$ dependent inactivation includes $\mathrm{Ca}^{2+}$ current-dependent inactivation and $\mathrm{Ca}^{2+}$ releasedependent inactivation. The former causes a slow phase inactivation and the latter causes a fast phase inactivation. Although both $\mathrm{Ca}^{2+}$ released from the $\mathrm{SR}$ and $\mathrm{Ca}^{2+}$ permeating through channels each play a role, SR-released $\mathrm{Ca}^{2+}$ is the more powerful inactivation mechanism [150].

In heart failure, $\mathrm{Ca}^{2+}$-induced $\mathrm{SR} \mathrm{Ca}^{2+}$ release is significantly diminished due to the diminished $\mathrm{SR} \mathrm{Ca}^{2+}$ content that stems from both reduced SERCA function and RyR leak. As a result, $\mathrm{I}_{\mathrm{Ca}}$ inactivation is significantly slowed in failing ventricular myocytes. In addition, recent work from our group showed that CaMKII-dependent mechanisms also contribute to the slowed $\mathrm{I}_{\mathrm{Ca}, \mathrm{L}}$ inactivation seen in load-induced heart failure[77]. Attenuation of frequency-dependent $\mathrm{Ca}^{2+}$-induced $\mathrm{I}_{\mathrm{Ca}}$ facilitation has been described in failing human $\mathrm{LV}$, pointing to a likely role of CaMKII in human heart failure[151]. In addition, spatial differences in remodeling of the transmural gradient of $\mathrm{I}_{\mathrm{Ca}, \mathrm{L}}$ have been reported, with reduced $\mathrm{I}_{\mathrm{Ca}, \mathrm{L}}$ in subendocardial cells and increased $\mathrm{I}_{\mathrm{Ca}, \mathrm{L}}$ in subepicardial and mid-myocardial cells[144]. In keeping with the findings reported in animal models with severe hypertrophy or failure, $\mathrm{I}_{\mathrm{Ca}, \mathrm{L}}$ in failing human ventricular myocytes also exhibits either no change[152,153] or a decrease in density[154]. However, one report described increases in channel open probability in failing human ventricular myocytes [155]. Abundance of the pore-forming $\alpha 1 \mathrm{c}$ subunit has been reported to be unchanged in failing human myocardium[156-159] or reduced[154,160]. In addition, a switch from the IVS3A to the IVS3B isoform of the $\alpha 1 \mathrm{c}$ subunit has been described in failing hearts[161].

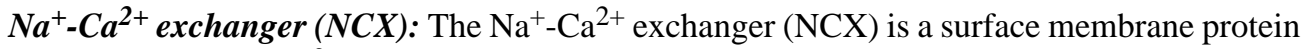
that transports one $\mathrm{Ca}^{2+}$ ion in exchange for $3 \mathrm{Na}^{+}$ions. Its activity is said to be "forward" when $\mathrm{Na}^{+}$is transported into the cell and $\mathrm{Ca}^{2+}$ is extruded outwards and "reverse" when ions are transported in the opposite directions. Most studies from hypertrophied and failing human hearts have demonstrated an increase in both NCX mRNA and protein levels[162-165], which has been posited to preserve diastolic extrusion of cytosolic $\mathrm{Ca}^{2+}$. At the same time, increased NCX activity may impair systolic function by favoring transport of $\mathrm{Ca}^{2+}$ out of the cell rather than back into intracellular stores. However, direct studies of NCX function in failing hearts are limited. In fact, NCX mRNA and protein levels are increased in pressure-overload ventricular hypertrophy, but direct measurements of NCX transport function, i.e. the $\mathrm{Na}^{+}$/ $\mathrm{Ca}^{2+}$ exchanger current $\left(\mathrm{I}_{\mathrm{NCX}}\right)$, revealed significant decreases, which may reflect diseaserelated alterations in the targeting of NCX protein to the sarcolemma[165,166]. In a rabbit model of HF induced by combined aortic insufficiency and aortic constriction, NCX mRNA level and the function were both found to be significantly increased[167,168].

$\mathrm{I}_{\mathrm{NCX}}$ can be arrhythmogenic, because inward current occurring during $\mathrm{Ca}^{2+}$ extrusion can give rise to delayed afterdepolarizations. Indeed, as a result of NCX up-regulation and inward rectifier potassium current (IK1) reduction, the propensity for triggered arrhythmias in $\mathrm{HF}$ is significantly increased[168]. Similar to animal models, increased NCX mRNA and protein abundances in failing human heart have been reported $[162,169]$. The functional role of the NCX in failing human myocardium is of greater importance to $\mathrm{Ca}^{2+}$-homeostasis than in nonfailing myocardium due to the altered function of SR[170]. However, the alterations of NCX in HF are controversial; unchanged levels of NCX protein in human heart failure have been reported[171,172], and some have reported a HF-related decrease in NCX expression[173] [174]. 
NCX likely plays a significant role in shaping the action potential profile. Forward-mode exchanger function generates an inward depolarizing current, contributing to APD prolongation. Conversely, computer simulations suggest that augmentation of reverse mode exchanger function during the early plateau would tend to shorten the action potential. However, some data suggest that the combination of forward mode function and delayed $\mathrm{I}_{\mathrm{Ca}, \mathrm{L}}$ inactivation together sum to prolong action potential duration[175]. It has been reported that direct blocking of NCX leads to different changes in APD, including a shortening[176], no change[177], or both shortening and prolongation depending on $\left[\mathrm{Na}^{+}\right]_{\mathrm{i}}[178]$. Also, intracellular $\mathrm{Na}^{+}$concentration $\left(\left[\mathrm{Na}^{+}\right]_{\mathrm{i}}\right)$ is an important determinant of the effect of $\mathrm{NCX}$ on APD. In the presence of high $\left[\mathrm{Na}^{+}\right]_{i}$ and low $\left[\mathrm{Ca}^{2+}\right]_{i}$, as seen in heart failure, there is a large NCX-dependent $\mathrm{Ca}^{2+}$ influx during the action potential[179], which ultimately mandates removal of this extra $\mathrm{Ca}^{2+}$ during the diastolic period. Given that the NCX is the most important efflux pathway, this would lead to a sustained inward current during diastole, contributing to APD prolongation, instability of the resting membrane potential, and triggered abnormal impulses[180].

Stretch-activated channels (SACs): Biomechanical signals external to the myocyte are capable of altering electrical activity[181], a potential arrhythmogenic influence in patients with congestive heart failure[182,183]. In fact, disordered mechano-electrical feedback is believed to contribute to arrhythmogenesis via mechanisms of membrane depolarization and modification of APD[184] [185].

Stretch-activated channels (SACs) are key mechanosensors of mechano-electrical signal transduction. SACs are nonselective cation channels[186] which allow $\mathrm{Na}^{+}, \mathrm{K}^{+}, \mathrm{Cs}^{+}$, and $\mathrm{Ca}^{2+}$ to permeate[187]. A linear current-voltage relationship has been described for SACs with reversal potentials between -6 and $-15 \mathrm{mV}$ in myocytes[186,188,189]. Stretch has been reported to depolarize resting membrane potential and to increase, decrease, or have a crossover effect on APD[190]. The inconsistent effect on APD may reflect differences stress-

responsiveness of isolated myocytes versus tissue or intact heart. Additionally, the different effects on APD may reflect the variety of experimental techniques used to stretch the myocardium and to track electrical activity.

The effects of myocardial stretch on APD arise from complex interactions between the SAC current and the other intrinsic membrane currents (and channels) present in myocytes. Even if the SAC conductance were to be constant during stretch, the time dependence and polarity of the SAC current are functions of myocyte membrane potential. For instance, with a constant reversal potential of $-10 \mathrm{mV}$, the SAC current would be inward during diastole but would switch to outward as the cell depolarizes. Further, the large variability in the repolarization process in ventricular myocytes across species (and in different regions of the ventricle) may significantly alter the effects of a given SAC current. In addition, the reversal potential of SAC varies across species. Thus, the role of SAC current in regulating myocyte depolarization and repolarization is complex and species-dependent. Furthermore, membrane potential measurements during dynamic axial stretching have shown that the action potential duration is prolonged when stretch is applied during the late phase of twitch contraction, and that membrane depolarization depends on the phase, amplitude, and speed of the applied stretch [191]. The amplitude of stretch may also modulate the ion selectivity of stretch-activated channels[191].

To isolate the effects of SAC current from the numerous other electrical events occurring in the cell, several mathematical models have been developed. An SAC simulation was incorporated into a guinea pig ventricular cell model, and SAC activation triggered EADs [192]. Recently, we modeled SAC in rat ventricular myocytes, finding that SAC activation elicited electrical changes in action potential repolarization similar to mechanical stretch, but 
it did not produce EADs[193]. However, in combination with oxidative stress, EADs were steadily induced by SAC activation, potentially implicating SACs in ventricular arrhythmias in cardiomyopathies with concomitant increased ventricular wall tension and oxidative stress. This SAC-related mechanism may explain, at least in part, the clinical findings that reducing myocardial wall tension and oxygen demand by mechanical unloading using intra-aortic balloon counterpulsation significantly reduces ventricular arrhythmias in heart failure patients with medically refractory ventricular arrhythmias[194]. In any event, owing to the technical difficulty of imposing physiologically relevant mechanical stretch and the nonselectivity of SAC ionic conductance, the arrhythmogenic role of SACs in heart failure is poorly understood.

\section{Tissue level electrical remodeling}

Tissue level electrical remodeling: Gap-junction remodeling: Gap junctions are specialized regions of membrane with densely packed channels called connexons that dock end-to-end and directly connect the cytoplasmic compartments of two adjacent myocytes. The number, size, and spatial distribution of gap junctions play an important role in determining the conduction properties of different cardiac tissues. Connexons are comprised of six monomers termed connexins. There are 3 connexins expressed in ventricular myocytes, connexin $40(\mathrm{Cx} 40)$, connexin 43 (Cx43), and connexin 45 (Cx45). Cx43 plays a major role in electrical conduction in myocytes[195,196], whereas Cx45 is likely less important owing to its low level of expression[197]. Connexin 40, a connexin associated with high conductance channels[198], is expressed mainly in the bundle branches and Purkinje fiber system[199,200].

In heart failure, gap junction expression is significantly reduced, redistributed, and disorganized[201-203]. As a result, the normal ordered pathways for cell-to-cell conduction are disrupted. A growing body of evidence from studies in animal models support the fact that gap junction remodeling is one of the key determinants of the pro-arrhythmic substrate in diseased heart. Altered distribution of connexin 43 gap junctions is a hallmark feature of infarct border zones in failing ventricle harvested at cardiac transplantation[201]. In these zones, connexin 43 gap junctions are scattered extensively over the cells, rather than clustered at regions of cell-cell contact. In experimental models of myocardial infarction, this redistribution has been shown to occur rapidly[204]. Similar alterations in gap junction distribution are found in ventricular hypertrophy and are associated with reduced longitudinal conduction velocity [205,206]. In end-stage heart failure, connexin 43 transcript and protein levels are markedly reduced[207]. In addition, hypophosphorylation of Cx43 due to elevated PP2A activity has been documented in failing LV [208,209], as well as spatially heterogeneous reductions in Cx43 expression (larger decreases in subepicardial than in deeper transmural layers)[210]. Thus, an expanding literature supports the hypothesis that gap junction remodeling is a key molecular feature contributing to both arrhythmia, and consequent sudden cardiac death (SCD), and exacerbating the ventricular dysfunction associated with acquired heart disease. Therefore, pathological remodeling of gap junctions is a therapeutic target of interest[211].

Conduction sequence remodeling: Normally, electrical activation of the ventricle initiates in the subendocardial Purkinje network and spreads outward through the ventricular wall.

Although the epicardium is activated last, it repolarizes faster than the endocardium; as a result, repolarization proceeds in the opposite direction, from epicardium to endocardium. The combination of in-to-out depolarization and out-to-in repolarization produces an electrocardiographic $\mathrm{T}$ wave on the surface ECG with polarity similar to the QRS. As noted earlier, we have reported attenuation of the transmural gradient of repolarization in failing LV, which abolishes preferential directionality of AP propagation[79].

In addition to the direct roles of altered myocardial repolarization in electrical conduction, disease-related remodeling can indirectly affect electrical stability via exaggerated anisotropy and altered cell-to-cell coupling. Chung et al. showed in an in vitro model that cardiac cell 
arrangement can alter electrical stability via mechanisms that are both dependent and independent of the direction of wave propagation[212]. Notably, restitution of APD and conduction velocity were significantly steepened in the direction of cell alignment. Furthermore, prolongation of APD and calcium transient duration were seen in highly anisotropic cell networks, both for longitudinal and transverse propagation[212]. Patients with structural disease have a wider diastolic interval range over which APD alternans occurs with earlier onset and increased magnitude of APD alternans compared with patients without structural heart disease[213]. The occurrence of APD alternans during induced ventricular tachycardia and during rapid pacing could be derived from the dynamic restitution function. This suggests that tissue alignment must be taken into account in experimental and computational models of arrhythmia generation and in designing effective treatment therapies.

Sarcoplasmic reticulum malfunction: The sarcoplasmic reticulum (SR) surrounds each myofibril and is physically separate from the sarcolemma. The SR membrane contains high levels of $\mathrm{Ca}^{2+}$-ATPase which serves to uptake $\mathrm{Ca}^{2+}$ from the sarcoplasm, a process leading to mechanical relaxation. $\mathrm{Ca}^{2+}$ is released into the sarcoplasm via ryanodine receptors (RyRs) during systole to trigger contraction.

In mammalian striated muscles, the expression of the different RyR protein isoforms is tissue specific. The predominant RyR isoform in skeletal muscle is RyR1, commonly referred to as the skeletal RyR isoform[214,215]. RyR2 protein is the most abundant isoform in cardiac muscle, while RyR3 is also found in mammalian striated muscles but at relatively low levels [216]. $\mathrm{Ca}^{2+}$ release from a cluster of ryanodine receptors results in a spatiotemporally-restricted rise in cytosolic $\mathrm{Ca}^{2+}$, which can be visualized as a calcium spark. Marx et al[217] showed that RyR2 assembles as a macromolecular signaling complex comprising FKBP12.6, the catalytic and regulatory subunit of PKA, PP1, PP2A, and a PKA-anchoring protein, mAKAP. The actual $\mathrm{Ca}^{2+}$-conducting channel is one of the constituents of an integrated macromolecular complex that specifically regulates channel $\mathrm{Ca}^{2+}$ gating. Studies in both heart failure models and in patients point to FKBP12.6 as a major regulatory element governing RyR2 function[217, 218]. The role of calcineurin on RyR function remains controversial and may be critically dependent on the RyR isoform.

Several groups have reported lack of significant alterations in RyR2 abundance in failing explanted human hearts compared with nonfailing controls[219-221], whereas other groups have reported a down-regulation of RyR2[222,223]. However, spontaneous RyR leakage of $\mathrm{Ca}^{2+}$ has been observed consistently in failing ventricular myocytes resulting from increased RYR phosphorylation by CaMKII[224-226] and PKA[217]. Most recent studies have pointed to CaMKII, but not PKA, in HF-related RyR $\mathrm{Ca}^{2+}$ leak[227,228].

Three distinct genes encode SERCA isoforms. The SERCA 1 gene is expressed in fast skeletal muscle, whereas the SERCA 2 gene gives rise to SERCA 2a and SERCA $2 b$ isoforms by alternative splicing. The SERCA $2 \mathrm{a}$ isoform is expressed in cardiac and slow skeletal muscle, while SERCA $2 \mathrm{~b}$ is ubiquitously expressed and is the dominant isoform found in the cerebellum. SERCA 3 is expressed in non-muscle tissues, such as platelets and lymphoid tissues[229,230].

The rate at which SERCA moves $\mathrm{Ca}^{2+}$ across the SR membrane is controlled by phospholamban (PLB). PLB is a 52 amino acid integral membrane protein that regulates the $\mathrm{Ca}^{2+}$ pump in both cardiac and skeletal muscle. In vitro studies have shown that PLB can be phosphorylated at $\mathrm{Ser}^{10}$ by protein kinase $\mathrm{C}$, at $\mathrm{Ser}^{16}$ by cAMP-dependent protein kinase (PKA), and at $\mathrm{Thr}^{17}$ by $\mathrm{Ca}^{2+}$-calmodulin-dependent protein kinase (CaMKII)[231-233]. However, in vivo studies have shown that only $\operatorname{Ser}^{16}$ and $\mathrm{Thr}^{17}$ are phosphorylated in cardiac myocytes[234,235]. Each phosphorylation event appears to occur independently[236-239]. 
Some studies have reported additive effects of PKA and CaMKII phosphorylation of PLB on $\mathrm{SR} \mathrm{Ca}^{2+}$ transport[236,237,240,241]; others have proposed that maximal stimulation of the $\mathrm{Ca}^{2+}$ pump occurs by phosphorylation at a single site[239,242], and additional phosphorylation events at other sites does not further stimulate pump activity[243]. In its unphosphorylated state, PLB associates with SERCA and inhibits the $\mathrm{Ca}^{2+}$-ATPase and its pumping of $\mathrm{Ca}^{2+}$. When phosphorylated PLB dissociates from the pump, $\mathrm{Ca}^{2+}$ movement increases. PP1 accounts for approximately $90 \%$ of phospholamban (Ser-16 or Thr-17) phosphatase activity [244].

Evidence now indicates that the levels of PLB protein remain unchanged in human heart failure, whereas the levels of SERCA2a protein decrease[220,245-249]. This would be expected to lead to an increased functional stoichiometry of PLB to SERCA, facilitating inhibition of SERCA2a $\mathrm{Ca}^{2+}$ pumping activity, and prolonged relaxation times. In addition, the phosphorylation status of PLB at Ser16 and Thr17 is decreased in heart failure[250], indicating that there is a yet further increase in the inhibitory function of PLB. Indeed, studies of SR $\mathrm{Ca}^{2+}$ uptake have revealed decreases in both Vmax and $\mathrm{Ca}^{2+}$ affinity in failing myocardium [245]. Thus, alterations in the PLB:SERCA2a ratio and the degree of PLB phosphorylation together likely contribute to reduced $\mathrm{SR} \mathrm{Ca}^{2+}$ uptake and increased diastolic $\mathrm{Ca}^{2+}$ levels in the cytoplasm. The resulting reduction of $\mathrm{SR} \mathrm{Ca}^{2+}$ content will, in turn, have a negative inotropic effect on contraction, and at the same time, reduce $\mathrm{Ca}^{2+}$-induced $\mathrm{Ca}^{2+}$ inactivation, leading to a slowed inactivation time course for $\mathrm{I}_{\mathrm{Ca}}$. This will, together with a prolonged APD, further increase diastolic $\mathrm{Ca}^{2+}$ and the propensity for triggered ventricular arrhythmias.

\section{Clinical relevance and perspective}

Disease-related electrical remodeling is a fundamental mechanism underlying the proarrhythmic phenotype of heart failure. Reductions in both transient outward and delayed rectifier $\mathrm{K}^{+}$currents contribute to prolongation of APD. Prolonged APD, in turn, promotes increased influx of $\mathrm{Ca}^{2+}$ during excitation. In addition, increases in NCX function and slowing of $\mathrm{I}_{\mathrm{Ca}, \mathrm{L}}$ inactivation contribute to $\mathrm{Ca}^{2+}$ overload. Further, prolongation of APD and abnormal handling of intracellular $\mathrm{Ca}^{2+}$ promote abnormal increases in focal activity and automaticity. In addition, heterogeneous APD prolongation within the ventricular wall amplifies dispersion of repolarization, an established mechanism contributing to re-entry. Finally, spatially different changes in $\mathrm{I}_{\text {to }}$ across the ventricular wall in heart failure alter cellular coupling current.

Together, these changes, along with the alteration of gap junctions and tissue alignment, lead to significant changes in electrical conductivity and sequence, which are important mechanisms underlying the increased propensity to ventricular arrhythmia and SCD in heart failure.

Recent studies have also raised the possibility that alterations in membrane currents may be proximal events contributing to cardiomyopathy. For example, $\mathrm{Ca}^{2+}$ entering through the Ltype voltage-dependent $\mathrm{Ca}^{2+}$ channel not only functions as a trigger for contraction but also transduces electrical activity into a series of intracellular signaling events. Numerous studies have demonstrated that increases in intracellular $\mathrm{Ca}^{2+}$ concentration may lead to contractile dysfunction, hypertrophy, and heart failure[76] and that " $\mathrm{Ca}^{2+}$ overload" may trigger downstream signaling cascades that initiate the hypertrophic gene program[251]. Enhanced sarcolemmal L-type $\mathrm{Ca}^{2+}$ channel activity can precipitate heart failure through myocyte necrosis[252]; in contrast, T-type currents can antagonize hypertrophy[253]. Also, whereas decreases in $\mathrm{I}_{\mathrm{to}}$ density have been regarded as secondary to the hypertrophic or failure phenotype, some evidence suggests that suppression of $\mathrm{I}_{\text {to }}$ could result in cardiac hypertrophy $[254,255]$. These data suggest that ion channel remodeling resulting from heart disease may contribute to the progression of heart disease. In addition, heart failure-related remodeling of one channel may trigger remodeling of other channels. For instance, we have reported that suppression of $\mathrm{I}_{\mathrm{to}}$ facilitates $\mathrm{I}_{\mathrm{Ca}, \mathrm{L}}$ in cardiac myocytes[256]. 
Nearly 6 million Americans live with heart failure, a syndrome marked by substantial morbidity and mortality from arrhythmia[1]. Indeed, arrhythmic sudden death is a leading cause of mortality in the Western world, with an estimated 300,000 cases per year in the United States [1]. Whereas the mechanism of mortality in heart failure depends on disease severity, some estimates suggest that death stems approximately equally from progressive pump failure, SCD, and SCD during episodes of clinical exacerbations of heart failure[1]. In addition to ventricular tachyarrhythmias, patients with heart failure experience a variety of other arrhythmias. For example, AF is very common in heart failure (11.8\%), is responsible for about $15-20 \%$ of all strokes[257], and contributes substantially to morbidity in heart failure.

The clinical efficacy of antiarrhythmic pharmacotherapy has proved disappointing in the majority of instances. However, recent insights into complex mechanisms of electrical remodeling have raised the prospect of targeting disease-related events contributing to the proarrhythmic substrate of the failing LV. Major challenges remain, but patients with heart disease are likely to benefit.

\section{Acknowledgments}

This work was supported by grants from the NIH (HL-088168, YW; HL083271, YW; HL-075173, JAH; HL-080144, JAH; HL-090842, JAH), AHA (0665178Y, YW; 0640084N, JAH), the NHF (H2007-019, YW), and the AHA-Jon Holden DeHaan Foundation (0970518N, JAH).

\section{References}

1. Lloyd-Jones D, Adams R, Carnethon M, De Simone G, Ferguson TB, Flegal K, et al. Heart disease and stroke statistics -- 2009 update: a report from the American Heart Association Statistics Committee and Stroke Statistics Subcommittee. Circulation Jan 27;2009 119(3):480-6. [PubMed: 19171871]

2. Hill JA, Olson EN. Cardiac plasticity. New Engl J Med 2008;358(13):1370-80. [PubMed: 18367740]

3. Tomaselli GF, Zipes DP. What causes sudden death in heart failure? Circ Res Oct 15;2004 95(8):75463. [PubMed: 15486322]

4. Nattel S, Maguy A, Le Bouter S, Yeh YH. Arrhythmogenic ion-channel remodeling in the heart: heart failure, myocardial infarction, and atrial fibrillation. Physiol Rev Apr;2007 87(2):425-56. [PubMed: 17429037]

5. Nass RD, Aiba T, Tomaselli GF, Akar FG. Mechanisms of disease: ion channel remodeling in the failing ventricle. Nat Clin Pract Cardiovasc Med Apr;2008 5(4):196-207. [PubMed: 18317475]

6. Bleeker WK, Mackaay AJ, Masson-Pevet M, Bouman LN, Becker AE. Functional and morphological organization of the rabbit sinus node. Circ Res Jan;1980 46(1):11-22. [PubMed: 7349910]

7. Boyett MR, Honjo H, Kodama I. The sinoatrial node, a heterogeneous pacemaker structure. Cardiovasc Res Sep;2000 47(4):658-87. [PubMed: 10974216]

8. Noma A, Morad M, Irisawa H. Does the "pacemaker current" generate the diastolic depolarization in the rabbit SA node cells? Pflugers Arch May;1983 397(3):190-4. [PubMed: 6878006]

9. DiFrancesco D. The contribution of the 'pacemaker' current (if) to generation of spontaneous activity in rabbit sino-atrial node myocytes. J Physiol Mar;1991 434:23-40. [PubMed: 2023118]

10. Jalife J. Mutual entrainment and electrical coupling as mechanisms for synchronous firing of rabbit sino-atrial pace-maker cells. J Physiol Nov;1984 356:221-43. [PubMed: 6097670]

11. Wu J, Schuessler RB, Rodefeld MD, Saffitz JE, Boineau JP. Morphological and membrane characteristics of spider and spindle cells isolated from rabbit sinus node. Am J Physiol Heart Circ Physiol Mar;2001 280(3):H1232-40. [PubMed: 11179068]

12. Accili EA, Robinson RB, DiFrancesco D. Properties and modulation of If in newborn versus adult cardiac SA node. Am J Physiol Mar;1997 272(3 Pt 2):H1549-52. [PubMed: 9087633]

13. Boyett MR, Dobrzynski H, Lancaster MK, Jones SA, Honjo H, Kodama I. Sophisticated architecture is required for the sinoatrial node to perform its normal pacemaker function. J Cardiovasc Electrophysiol Jan;2003 14(1):104-6. [PubMed: 12625620] 
14. Dokos S, Celler B, Lovell N. Ion currents underlying sinoatrial node pacemaker activity: a new single cell mathematical model. J Theor Biol Aug 7;1996 181(3):245-72. [PubMed: 8869126]

15. Hagiwara N, Irisawa H, Kameyama M. Contribution of two types of calcium currents to the pacemaker potentials of rabbit sino-atrial node cells. J Physiol Jan;1988 395:233-53. [PubMed: 2457676]

16. Doerr T, Denger R, Trautwein W. Calcium currents in single SA nodal cells of the rabbit heart studied with action potential clamp. Pflugers Arch Apr;1989 413(6):599-603. [PubMed: 2726423]

17. Perez-Reyes E. Molecular physiology of low-voltage-activated t-type calcium channels. Physiol Rev Jan;2003 83(1):117-61. [PubMed: 12506128]

18. Opthof T, Coronel R, Rademaker HM, Vermeulen JT, Wilms-Schopman FJ, Janse MJ. Changes in sinus node function in a rabbit model of heart failure with ventricular arrhythmias and sudden death. Circulation Jun 27;2000 101(25):2975-80. [PubMed: 10869272]

19. Sanders P, Kistler PM, Morton JB, Spence SJ, Kalman JM. Remodeling of sinus node function in patients with congestive heart failure: reduction in sinus node reserve. Circulation Aug 24;2004 110 (8):897-903. [PubMed: 15302799]

20. Jose AD, Collison D. The normal range and determinants of the intrinsic heart rate in man. Cardiovasc Res Apr;1970 4(2):160-7. [PubMed: 4192616]

21. Witte K, Hu K, Swiatek J, Mussig C, Ertl G, Lemmer B. Experimental heart failure in rats: effects on cardiovascular circadian rhythms and on myocardial beta-adrenergic signaling. Cardiovasc Res Aug;2000 47(2):350-8. [PubMed: 10946071]

22. Verkerk AO, Wilders R, Coronel R, Ravesloot JH, Verheijck EE. Ionic remodeling of sinoatrial node cells by heart failure. Circulation Aug 12;2003 108(6):760-6. [PubMed: 12885752]

23. Leoni AL, Marionneau C, Demolombe S, Le Bouter S, Mangoni ME, Escande D, et al. Chronic heart rate reduction remodels ion channel transcripts in the mouse sinoatrial node but not in the ventricle. Physiol Genomics Dec 14;2005 24(1):4-12. [PubMed: 16219869]

24. Elvan A. Sinoatrial remodeling caused by persistent atrial fibrillation: what is the relationship between postcardioversion sinus node dysfunction and increased atrial vulnerability? J Cardiovasc Electrophysiol Jul;2001 12(7):807-8. [PubMed: 11469432]

25. Hadian D, Zipes DP, Olgin JE, Miller JM. Short-term rapid atrial pacing produces electrical remodeling of sinus node function in humans. J Cardiovasc Electrophysiol Jun;2002 13(6):584-6. [PubMed: 12108502]

26. Zicha S, Fernandez-Velasco M, Lonardo G, L'Heureux N, Nattel S. Sinus node dysfunction and hyperpolarization-activated $(\mathrm{HCN})$ channel subunit remodeling in a canine heart failure model. Cardiovasc Res Jun 1;2005 66(3):472-81. [PubMed: 15914112]

27. Manios EG, Kanoupakis EM, Mavrakis HE, Kallergis EM, Dermitzaki DN, Vardas PE. Sinus pacemaker function after cardioversion of chronic atrial fibrillation: is sinus node remodeling related with recurrence? J Cardiovasc Electrophysiol Jul;2001 12(7):800-6. [PubMed: 11469431]

28. Meijler FL, Janse MJ. Morphology and electrophysiology of the mammalian atrioventricular node. Physiol Rev Apr;1988 68(2):608-47. [PubMed: 2451833]

29. Mazgalev TN, Ho SY, Anderson RH. Anatomic-electrophysiological correlations concerning the pathways for atrioventricular conduction. Circulation Jun 5;2001 103(22):2660-7. [PubMed: 11390334]

30. Tilley DG, Rockman HA. Role of beta-adrenergic receptor signaling and desensitization in heart failure: new concepts and prospects for treatment. Expert Rev Cardiovasc Ther May;2006 4(3):41732. [PubMed: 16716102]

31. Nayebpour M, Talajic M, Nattel S. Effects of beta-adrenergic receptor stimulation and blockade on rate-dependent atrioventricular nodal properties. Circ Res May;1992 70(5):902-11. [PubMed: 1348976]

32. Bristow MR. beta-adrenergic receptor blockade in chronic heart failure. Circulation Feb 8;2000 101 (5):558-69. [PubMed: 10662755]

33. Khoo MS, Kannankeril PJ, Li J, Zhang R, Kupershmidt S, Zhang W, et al. Calmodulin kinase II activity is required for normal atrioventricular nodal conduction. Heart Rhythm Jun;2005 2(6):63440. [PubMed: 15922273] 
34. Vinogradova TM, Zhou YY, Bogdanov KY, Yang D, Kuschel M, Cheng H, et al. Sinoatrial node pacemaker activity requires $\mathrm{Ca}(2+)$ /calmodulin-dependent protein kinase II activation. Circ Res Oct 27;2000 87(9):760-7. [PubMed: 11055979]

35. Rigg L, Mattick PA, Heath BM, Terrar DA. Modulation of the hyperpolarization-activated current (I(f)) by calcium and calmodulin in the guinea-pig sino-atrial node. Cardiovasc Res Feb;2003 57(2): 497-504. [PubMed: 12566122]

36. Wu Y, Gao Z, Chen B, Koval OM, Singh MV, Guan X, et al. Calmodulin kinase II is required for fight or flight sinoatrial node physiology. Proc Natl Acad Sci U S A Apr 7;2009 106(14):5972-7. [PubMed: 19276108]

37. Purkyně JE. Mikroskopisch-neurologische Beobachtungen. Archf Anat Physiol wiss Med 1845;12:281-95.

38. El-Sherif N, Chinushi M, Caref EB, Restivo M. Electrophysiological mechanism of the characteristic electrocardiographic morphology of torsade de pointes tachyarrhythmias in the long-QT syndrome: detailed analysis of ventricular tridimensional activation patterns. Circulation Dec 16;1997 96(12): 4392-9. [PubMed: 9416909]

39. Berenfeld O, Jalife J. Purkinje-muscle reentry as a mechanism of polymorphic ventricular arrhythmias in a 3-dimensional model of the ventricles. Circ Res Jun 1;1998 82(10):1063-77. [PubMed: 9622159]

40. Boyden PA, Pinto JM. Reduced calcium currents in subendocardial Purkinje myocytes that survive in the 24- and 48-hour infarcted heart. Circulation Jun;1994 89(6):2747-59. [PubMed: 8205689]

41. Jeck C, Pinto J, Boyden P. Transient outward currents in subendocardial Purkinje myocytes surviving in the infarcted heart. Circulation Aug 1;1995 92(3):465-73. [PubMed: 7634462]

42. Pinto JM, Boyden PA. Reduced inward rectifying and increased E-4031-sensitive K+ current density in arrhythmogenic subendocardial purkinje myocytes from the infarcted heart. J Cardiovasc Electrophysiol Mar;1998 9(3):299-311. [PubMed: 9554735]

43. Lehmann MH, Hardy S, Archibald D, quart B, MacNeil DJ. Sex difference in risk of torsade de pointes with d,1-sotalol. Circulation Nov 15;1996 94(10):2535-41. [PubMed: 8921798]

44. Han W, Chartier D, Li D, Nattel S. Ionic remodeling of cardiac Purkinje cells by congestive heart failure. Circulation Oct 23;2001 104(17):2095-100. [PubMed: 11673352]

45. Knight BP. Atrial fibrillation in patients with congestive heart failure. Pacing Clin Electrophysiol Jul; 2003 26(7 Pt 2):1620-3. [PubMed: 12914612]

46. Wijffels MC, Kirchhof CJ, Dorland R, Allessie MA. Atrial fibrillation begets atrial fibrillation. A study in awake chronically instrumented goats. Circulation Oct 1;1995 92(7):1954-68. [PubMed: 7671380]

47. Li D, Melnyk P, Feng J, Wang Z, Petrecca K, Shrier A, et al. Effects of experimental heart failure on atrial cellular and ionic electrophysiology. Circulation Jun 6;2000 101(22):2631-8. [PubMed: 10840016]

48. Estes NA 3rd, Halperin JL, Calkins H, Ezekowitz MD, Gitman P, Go AS, et al. ACC/AHA/Physician Consortium 2008 clinical performance measures for adults with nonvalvular atrial fibrillation or atrial flutter: a report of the American College of Cardiology/American Heart Association Task Force on Performance Measures and the Physician Consortium for Performance Improvement (Writing Committee to Develop Clinical Performance Measures for Atrial Fibrillation): developed in collaboration with the Heart Rhythm Society. Circulation Feb 26;2008 117(8):1101-20. [PubMed: 18283199]

49. Wright M, Haissaguerre M, Knecht S, Matsuo S, O'Neill MD, Nault I, et al. State of the art: catheter ablation of atrial fibrillation. J Cardiovasc Electrophysiol Jun;2008 19(6):583-92. [PubMed: 18462322]

50. Savelieva I, Camm J. Update on atrial fibrillation: part I. Clin Cardiol Feb;2008 31(2):55-62. [PubMed: 18257025]

51. Savelieva I, Camm J. Update on atrial fibrillation: part II. Clin Cardiol Mar;2008 31(3):102-8. [PubMed: 18383050]

52. Biffi M, Boriani G, Bartolotti M, Bacchi Reggiani L, Zannoli R, Branzi A. Atrial fibrillation recurrence after internal cardioversion: prognostic importance of electrophysiological parameters. Heart May;2002 87(5):443-8. [PubMed: 11997417] 
53. Yue L, Feng J, Gaspo R, Li GR, Wang Z, Nattel S. Ionic remodeling underlying action potential changes in a canine model of atrial fibrillation. Circ Res Oct;1997 81(4):512-25. [PubMed: 9314832]

54. Ramirez RJ, Nattel S, Courtemanche M. Mathematical analysis of canine atrial action potentials: rate, regional factors, and electrical remodeling. Am J Physiol Heart Circ Physiol Oct;2000 279 (4):H1767-85. [PubMed: 11009464]

55. Skasa M, Jungling E, Picht E, Schondube F, Luckhoff A. L-type calcium currents in atrial myocytes from patients with persistent and non-persistent atrial fibrillation. Basic Res Cardiol Apr;2001 96(2): 151-9. [PubMed: 11327333]

56. Workman AJ, Kane KA, Rankin AC. The contribution of ionic currents to changes in refractoriness of human atrial myocytes associated with chronic atrial fibrillation. Cardiovasc Res Nov;2001 52(2): 226-35. [PubMed: 11684070]

57. Nattel S. New ideas about atrial fibrillation 50 years on. Nature Jan 10;2002 415(6868):219-26. [PubMed: 11805846]

58. Yue L, Melnyk P, Gaspo R, Wang Z, Nattel S. Molecular mechanisms underlying ionic remodeling in a dog model of atrial fibrillation. Circ Res Apr 16;1999 84(7):776-84. [PubMed: 10205145]

59. Jaleel N, Nakayama H, Chen X, Kubo H, MacDonnell S, Zhang H, et al. Ca2+ influx through T- and L-type $\mathrm{Ca} 2+$ channels have different effects on myocyte contractility and induce unique cardiac phenotypes. Circ Res Nov 7;2008 103(10):1109-19. [PubMed: 18832749]

60. Lee SH, Yu WC, Cheng JJ, Hung CR, Ding YA, Chang MS, et al. Effect of verapamil on long-term tachycardia-induced atrial electrical remodeling. Circulation Jan 18;2000 101(2):200-6. [PubMed: 10637209]

61. Fareh S, Benardeau A, Thibault B, Nattel S. The T-type $\mathrm{Ca}(2+)$ channel blocker mibefradil prevents the development of a substrate for atrial fibrillation by tachycardia-induced atrial remodeling in dogs. Circulation Nov 23;1999 100(21):2191-7. [PubMed: 10571979]

62. Fareh S, Benardeau A, Nattel S. Differential efficacy of L- and T-type calcium channel blockers in preventing tachycardia-induced atrial remodeling in dogs. Cardiovasc Res Mar;2001 49(4):762-70. [PubMed: 11230975]

63. Schreieck J, Wang Y, Overbeck M, Schomig A, Schmitt C. Altered transient outward current in human atrial myocytes of patients with reduced left ventricular function. J Cardiovasc Electrophysiol Feb;2000 11(2):180-92. [PubMed: 10709713]

64. Kumagai K, Akimitsu S, Kawahira K, Kawanami F, Yamanouchi Y, Hiroki T, et al. Electrophysiological properties in chronic lone atrial fibrillation. Circulation Oct;1991 84(4):16628. [PubMed: 1914105]

65. Sanders P, Morton JB, Davidson NC, Spence SJ, Vohra JK, Sparks PB, et al. Electrical remodeling of the atria in congestive heart failure: electrophysiological and electroanatomic mapping in humans. Circulation Sep 23;2003 108(12):1461-8. [PubMed: 12952837]

66. Shinagawa K, Shi YF, Tardif JC, Leung TK, Nattel S. Dynamic nature of atrial fibrillation substrate during development and reversal of heart failure in dogs. Circulation Jun 4;2002 105(22):2672-8. [PubMed: 12045175]

67. Ohtani K, Yutani C, Nagata S, Koretsune Y, Hori M, Kamada T. High prevalence of atrial fibrosis in patients with dilated cardiomyopathy. J Am Coll Cardiol Apr;1995 25(5):1162-9. [PubMed: 7897130]

68. Kostin S, Klein G, Szalay Z, Hein S, Bauer EP, Schaper J. Structural correlate of atrial fibrillation in human patients. Cardiovasc Res May;2002 54(2):361-79. [PubMed: 12062341]

69. Boldt A, Wetzel U, Lauschke J, Weigl J, Gummert J, Hindricks G, et al. Fibrosis in left atrial tissue of patients with atrial fibrillation with and without underlying mitral valve disease. Heart Apr;2004 90(4):400-5. [PubMed: 15020515]

70. Li D, Fareh S, Leung TK, Nattel S. Promotion of atrial fibrillation by heart failure in dogs: atrial remodeling of a different sort. Circulation Jul 6;1999 100(1):87-95. [PubMed: 10393686]

71. Akar FG, Tomaselli GF. Ion channels as novel therapeutic targets in heart failure. Ann Med 2005;37 (1):44-54. [PubMed: 15902846]

72. Cutler MJ, Rosenbaum DS, Dunlap ME. Structural and electrical remodeling as therapeutic targets in heart failure. J Electrocardiol Nov-Dec;2007 40(6 Suppl):S1-7. [PubMed: 17993305] 
73. Kaab S, Nuss HB, Chiamvimonvat N, O'Rourke B, Pak PH, Kass DA, et al. Ionic mechanism of action potential prolongation in ventricular myocytes from dogs with pacing-induced heart failure. Circ Res Feb;1996 78(2):262-73. [PubMed: 8575070]

74. Kaab S, Dixon J, Duc J, Ashen D, Nabauer M, Beuckelmann DJ, et al. Molecular basis of transient outward potassium current downregulation in human heart failure: a decrease in Kv4.3 mRNA correlates with a reduction in current density. Circulation Oct 6;1998 98(14):1383-93. [PubMed: 9760292]

75. O'Rourke B, Kass DA, Tomaselli GF, Kaab S, Tunin R, Marban E. Mechanisms of altered excitationcontraction coupling in canine tachycardia-induced heart failure, I: experimental studies. Circ Res Mar 19;1999 84(5):562-70. [PubMed: 10082478]

76. Houser SR, Piacentino V 3rd, Weisser J. Abnormalities of calcium cycling in the hypertrophied and failing heart. J Mol Cell Cardiol Sep;2000 32(9):1595-607. [PubMed: 10966823]

77. Wang Y, Tandan S, Cheng J, Yang C, Nguyen L, Sugianto J, et al. Ca2+/calmodulin-dependent protein kinase II-dependent remodeling of $\mathrm{Ca} 2+$ current in pressure overload heart failure. $\mathrm{J}$ Biol Chem Sep 12;2008 283(37):25524-32. [PubMed: 18622016]

78. Undrovinas AI, Maltsev VA, Sabbah HN. Repolarization abnormalities in cardiomyocytes of dogs with chronic heart failure: role of sustained inward current. Cell Mol Life Sci Mar;1999 55(3):494505. [PubMed: 10228563]

79. Wang Y, Cheng J, Joyner RW, Wagner MB, Hill JA. Remodeling of early-phase repolarization: a mechanism of abnormal impulse conduction in heart failure. Circulation Apr 18;2006 113(15):184956. [PubMed: 16618832]

80. Akar FG, Rosenbaum DS. Transmural electrophysiological heterogeneities underlying arrhythmogenesis in heart failure. Circ Res Oct 3;2003 93(7):638-45. [PubMed: 12933704]

81. Li GR, Lau CP, Ducharme A, Tardif JC, Nattel S. Transmural action potential and ionic current remodeling in ventricles of failing canine hearts. Am J Physiol Heart Circ Physiol Sep;2002 283 (3):H1031-41. [PubMed: 12181133]

82. Clancy CE, Kass RS. Defective cardiac ion channels: from mutations to clinical syndromes. J Clin Invest Oct;2002 110(8):1075-7. [PubMed: 12393842]

83. Brown AM, Schwindt PC, Crill WE. Different voltage dependence of transient and persistent Na+ currents is compatible with modal-gating hypothesis for sodium channels. J Neurophysiol Jun;1994 71(6):2562-5. [PubMed: 7931536]

84. Belardinelli L, Shryock JC, Fraser H. Inhibition of the late sodium current as a potential cardioprotective principle: effects of the late sodium current inhibitor ranolazine. Heart Jul;2006 92 (Suppl 4):iv6-iv14. [PubMed: 16775092]

85. Maltsev VA, Sabbab HN, Undrovinas AI. Down-regulation of sodium current in chronic heart failure: effect of long-term therapy with carvedilol. Cell Mol Life Sci Sep;2002 59(9):1561-8. [PubMed: 12440776]

86. Jacques D, Bkaily G, Jasmin G, Menard D, Proschek L. Early fetal like slow Na+ current in heart cells of cardiomyopathic hamster. Mol Cell Biochem Nov;1997 176(1-2):249-56. [PubMed: 9406169]

87. Huang B, El-Sherif T, Gidh-Jain M, Qin D, El-Sherif N. Alterations of sodium channel kinetics and gene expression in the postinfarction remodeled myocardium. J Cardiovasc Electrophysiol Feb;2001 12(2):218-25. [PubMed: 11232622]

88. Maltsev VA, Silverman N, Sabbah HN, Undrovinas AI. Chronic heart failure slows late sodium current in human and canine ventricular myocytes: implications for repolarization variability. Eur $\mathbf{J}$ Heart Fail Mar;2007 9(3):219-27. [PubMed: 17067855]

89. Maltsev VA, Sabbah HN, Higgins RS, Silverman N, Lesch M, Undrovinas AI. Novel, ultraslow inactivating sodium current in human ventricular cardiomyocytes. Circulation Dec 8;1998 98(23): 2545-52. [PubMed: 9843461]

90. Valdivia CR, Chu WW, Pu J, Foell JD, Haworth RA, Wolff MR, et al. Increased late sodium current in myocytes from a canine heart failure model and from failing human heart. J Mol Cell Cardiol Mar; 2005 38(3):475-83. [PubMed: 15733907] 
91. Shieh CC, Coghlan M, Sullivan JP, Gopalakrishnan M. Potassium channels: molecular defects, diseases, and therapeutic opportunities. Pharmacol Rev Dec;2000 52(4):557-94. [PubMed: 11121510]

92. Wulff H, Castle NA, Pardo LA. Voltage-gated potassium channels as therapeutic targets. Nat Rev Drug Discov Dec;2009 8(12):982-1001. [PubMed: 19949402]

93. Patel SP, Campbell DL. Transient outward potassium current, 'Ito', phenotypes in the mammalian left ventricle: underlying molecular, cellular and biophysical mechanisms. J Physiol Nov 15;2005 569(Pt 1):7-39. [PubMed: 15831535]

94. Oudit GY, Kassiri Z, Sah R, Ramirez RJ, Zobel C, Backx PH. The molecular physiology of the cardiac transient outward potassium current (I(to)) in normal and diseased myocardium. J Mol Cell Cardiol May;2001 33(5):851-72. [PubMed: 11343410]

95. Kaab S, Dixon J, Duc J, Ashen D, Nabauer M, Beuckelmann DJ, et al. Molecular basis of transient outward potassium current downregulation in human heart failure: A decrease in Kv4.3 mRNA correlates with a reduction in current density. Circulation 1998;98(14):1383-93. 1998/10/06/. [PubMed: 9760292]

96. Rosati B, Pan Z, Lypen S, Wang HS, Cohen I, Dixon JE, et al. Regulation of KChIP2 potassium channel beta subunit gene expression underlies the gradient of transient outward current in canine and human ventricle. J Physiol May 15;2001 533(Pt 1):119-25. [PubMed: 11351020]

97. Rosati B, Grau F, Rodriguez S, Li H, Nerbonne JM, McKinnon D. Concordant expression of KChIP2 mRNA, protein and transient outward current throughout the canine ventricle. J Physiol May 1;2003 548(Pt 3):815-22. [PubMed: 12598586]

98. Kaprielian R, Wickenden AD, Kassiri Z, Parker TG, Liu PP, Backx PH. Relationship between K+ channel down-regulation and $[\mathrm{Ca} 2+] \mathrm{i}$ in rat ventricular myocytes following myocardial infarction. $\mathrm{J}$ Physiol May 15;1999 517(Pt 1):229-45. [PubMed: 10226162]

99. Beuckelmann DJ, Nabauer M, Erdmann E. Alterations of $\mathrm{K}+$ currents in isolated human ventricular myocytes from patients with terminal heart failure. Circ Res Aug;1993 73(2):379-85. [PubMed: 8330380]

100. Le Grand BL, Hatem S, Deroubaix E, Couetil JP, Coraboeuf E. Depressed transient outward and calcium currents in dilated human atria. Cardiovasc Res Apr;1994 28(4):548-56. [PubMed: 8181045]

101. Wang HS, Dixon JE, McKinnon D. Unexpected and differential effects of Cl- channel blockers on the Kv4.3 and Kv4.2 K+ channels. Implications for the study of the I(to2) current. Circ Res Nov; 1997 81(5):711-8. [PubMed: 9351445]

102. Beuckelmann DJ, Nabauer M, Kruger C, Erdmann E. Altered diastolic [Ca2+]i handling in human ventricular myocytes from patients with terminal heart failure. Am Heart J Apr;1995 129(4):6849. [PubMed: 7900618]

103. Litovsky SH, Antzelevitch C. Rate dependence of action potential duration and refractoriness in canine ventricular endocardium differs from that of epicardium: role of the transient outward current. J Am Coll Cardiol Oct;1989 14(4):1053-66. [PubMed: 2551947]

104. Zygmunt AC, Robitelle DC, Eddlestone GT. Ito1 dictates behavior of $\mathrm{ICl}(\mathrm{Ca})$ during early repolarization of canine ventricle. Am J Physiol Sep;1997 273(3 Pt 2):H1096-106. [PubMed: 9321794]

105. Volk T, Nguyen TH, Schultz JH, Ehmke H. Relationship between transient outward K+ current and $\mathrm{Ca} 2+$ influx in rat cardiac myocytes of endo- and epicardial origin. J Physiol Sep 15;1999 519(Pt 3):841-50. [PubMed: 10457095]

106. Greenstein JL, Wu R, Po S, Tomaselli GF, Winslow RL. Role of the calcium-independent transient outward current I(to1) in shaping action potential morphology and duration. Circ Res Nov 24;2000 87(11):1026-33. [PubMed: 11090548]

107. Sah R, Ramirez RJ, Kaprielian R, Backx PH. Alterations in action potential profile enhance excitation-contraction coupling in rat cardiac myocytes. J Physiol May 15;2001 533(Pt 1):201-14. [PubMed: 11351028]

108. Wang YG, Wagner MB, Kumar R, Goolsby WN, Joyner RW. Fast pacing facilitates discontinuous action potential propagation between rabbit atrial cells. Am J Physiol Heart Circ Physiol Nov;2000 279(5):H2095-103. [PubMed: 11045942] 
109. Medina-Ravell VA, Lankipalli RS, Yan GX, Antzelevitch C, Medina-Malpica NA, Medina-Malpica $\mathrm{OA}$, et al. Effect of epicardial or biventricular pacing to prolong QT interval and increase transmural dispersion of repolarization: does resynchronization therapy pose a risk for patients predisposed to long QT or torsade de pointes? Circulation Feb 11;2003 107(5):740-6. [PubMed: 12578878]

110. Bristow MR, Saxon LA, Boehmer J, Krueger S, Kass DA, De Marco T, et al. Cardiacresynchronization therapy with or without an implantable defibrillator in advanced chronic heart failure. N Engl J Med May 20;2004 350(21):2140-50. [PubMed: 15152059]

111. Tamargo J, Caballero R, Gomez R, Valenzuela C, Delpon E. Pharmacology of cardiac potassium channels. Cardiovasc Res Apr 1;2004 62(1):9-33. [PubMed: 15023549]

112. Roden DM. Clinical practice. Long-QT syndrome. N Engl J Med Jan 10;2008 358(2):169-76. [PubMed: 18184962]

113. Vandenberg JI, Walker BD, Campbell TJ. HERG K+ channels: friend and foe. Trends Pharmacol Sci May;2001 22(5):240-6. [PubMed: 11339975]

114. Jurkiewicz NK, Sanguinetti MC. Rate-dependent prolongation of cardiac action potentials by a methanesulfonanilide class III antiarrhythmic agent. Specific block of rapidly activating delayed rectifier K+ current by dofetilide. Circ Res Jan;1993 72(1):75-83. [PubMed: 8417848]

115. Lengyel C, Iost N, Virag L, Varro A, Lathrop DA, Papp JG. Pharmacological block of the slow component of the outward delayed rectifier current $(\mathrm{I}(\mathrm{Ks}))$ fails to lengthen rabbit ventricular muscle QT(c) and action potential duration. Br J Pharmacol Jan;2001 132(1):101-10. [PubMed: 11156566]

116. Varro A, Balati B, Iost N, Takacs J, Virag L, Lathrop DA, et al. The role of the delayed rectifier component IKs in dog ventricular muscle and Purkinje fibre repolarization. J Physiol Feb 15;2000 523(Pt 1):67-81. [PubMed: 10675203]

117. Tsuji Y, Opthof T, Kamiya K, Yasui K, Liu W, Lu Z, et al. Pacing-induced heart failure causes a reduction of delayed rectifier potassium currents along with decreases in calcium and transient outward currents in rabbit ventricle. Cardiovasc Res Nov;2000 48(2):300-9. [PubMed: 11054476]

118. Kleiman RB, Houser SR. Outward currents in normal and hypertrophied feline ventricular myocytes. Am J Physiol May;1989 256(5 Pt 2):H1450-61. [PubMed: 2524172]

119. Furukawa T, Bassett AL, Furukawa N, Kimura S, Myerburg RJ. The ionic mechanism of reperfusioninduced early afterdepolarizations in feline left ventricular hypertrophy. J Clin Invest Apr;1993 91 (4):1521-31. [PubMed: 8386189]

120. Volders PG, Sipido KR, Vos MA, Spatjens RL, Leunissen JD, Carmeliet E, et al. Downregulation of delayed rectifier $\mathrm{K}(+)$ currents in dogs with chronic complete atrioventricular block and acquired torsades de pointes. Circulation Dec 14;1999 100(24):2455-61. [PubMed: 10595960]

121. Xu X, Rials SJ, Wu Y, Salata JJ, Liu T, Bharucha DB, et al. Left ventricular hypertrophy decreases slowly but not rapidly activating delayed rectifier potassium currents of epicardial and endocardial myocytes in rabbits. Circulation Mar 20;2001 103(11):1585-90. [PubMed: 11257089]

122. Brooksby P, Levi AJ, Jones JV. The electrophysiological characteristics of hypertrophied ventricular myocytes from the spontaneously hypertensive rat. J Hypertens Jun;1993 11(6):611-22. [PubMed: 8397240]

123. Ryder KO, Bryant SM, Hart G. Changes in cell length consequent on depolarization in single left ventricular myocytes from guinea-pigs with pressure-overload left ventricular hypertrophy. Proc Biol Sci Jul 22;1993 253(1336):35-42. [PubMed: 8396776]

124. Tomaselli GF, Marban E. Electrophysiological remodeling in hypertrophy and heart failure. Cardiovasc Res May;1999 42(2):270-83. [PubMed: 10533566]

125. Tsuji Y, Zicha S, Qi XY, Kodama I, Nattel S. Potassium channel subunit remodeling in rabbits exposed to long-term bradycardia or tachycardia: discrete arrhythmogenic consequences related to differential delayed-rectifier changes. Circulation Jan 24;2006 113(3):345-55. [PubMed: 16432066]

126. Noma A. ATP-regulated K+ channels in cardiac muscle. Nature Sep 8-14;1983 305(5930):147-8. [PubMed: 6310409]

127. Schwappach B, Zerangue N, Jan YN, Jan LY. Molecular basis for K(ATP) assembly: transmembrane interactions mediate association of a $\mathrm{K}+$ channel with an ABC transporter. Neuron Apr;2000 26(1): 155-67. [PubMed: 10798400] 
128. Burke MA, Mutharasan RK, Ardehali H. The sulfonylurea receptor, an atypical ATP-binding cassette protein, and its regulation of the KATP channel. Circ Res Feb 1;2008 102(2):164-76. [PubMed: 18239147]

129. Kane GC, Liu XK, Yamada S, Olson TM, Terzic A. Cardiac KATP channels in health and disease. J Mol Cell Cardiol Jun;2005 38(6):937-43. [PubMed: 15910878]

130. Babenko AP, Gonzalez G, Aguilar-Bryan L, Bryan J. Reconstituted human cardiac KATP channels: functional identity with the native channels from the sarcolemma of human ventricular cells. Circ Res Nov 30;1998 83(11):1132-43. [PubMed: 9831708]

131. Fujita A, Kurachi Y. Molecular aspects of ATP-sensitive K+ channels in the cardiovascular system and K+ channel openers. Pharmacol Ther Jan;2000 85(1):39-53. [PubMed: 10674713]

132. Mannhold R. KATP channel openers: structure-activity relationships and therapeutic potential. Med Res Rev Mar;2004 24(2):213-66. [PubMed: 14705169]

133. Hodgson DM, Zingman LV, Kane GC, Perez-Terzic C, Bienengraeber M, Ozcan C, et al. Cellular remodeling in heart failure disrupts K(ATP) channel-dependent stress tolerance. EMBO J Apr 15;2003 22(8):1732-42. [PubMed: 12682006]

134. Miyazaki T, Moritani K, Miyoshi S, Asanagi M, Zhao LS, Mitamura H, et al. Nicorandil augments regional ischemia-induced monophasic action potential shortening and potassium accumulation without serious proarrhythmia. J Cardiovasc Pharmacol Dec;1995 26(6):949-56. [PubMed: 8606533]

135. Ueda H, Nakayama Y, Tsumura K, Yoshimaru K, Hayashi T, Yoshikawa J. Intravenous nicorandil can reduce the occurrence of ventricular fibrillation and QT dispersion in patients with successful coronary angioplasty in acute myocardial infarction. Can J Cardiol May 1;2004 20(6):625-9. [PubMed: 15152293]

136. De Waard M, Gurnett CA, Campbell KP. Structural and functional diversity of voltage-activated calcium channels. Ion Channels 1996;4:41-87. [PubMed: 8744206]

137. Walker D, De Waard M. Subunit interaction sites in voltage-dependent Ca2+ channels: role in channel function. Trends Neurosci Apr;1998 21(4):148-54. [PubMed: 9554724]

138. Kamp TJ, Hell JW. Regulation of cardiac L-type calcium channels by protein kinase A and protein kinase C. Circ Res 2000;87:1095-102. 2000///. [PubMed: 11110765]

139. Pitt GS, Dun W, Boyden PA. Remodeled cardiac calcium channels. J Mol Cell Cardiol Sep;2006 41(3):373-88. [PubMed: 16901502]

140. Tandan S, Wang Y, Wang TT, Jiang N, Hall DD, Hell JW, et al. Physical and functional interaction between calcineurin and the cardiac L-type Ca2+ channel. Circ Res Jul 2;2009 105(1):51-60. [PubMed: 19478199]

141. Wang HS, Cohen IS. Calcium channel heterogeneity in canine left ventricular myocytes. J Physiol Mar 15;2003 547(Pt 3):825-33. [PubMed: 12562927]

142. Pandit SV, Clark RB, Giles WR, Demir SS. A mathematical model of action potential heterogeneity in adult rat left ventricular myocytes. Biophys J Dec;2001 81(6):3029-51. [PubMed: 11720973]

143. Wang Y, Tandan S, Cheng J, Yang C, Nguyen L, Sugianto J, et al. CaMKII-dependent remodeling of Ca2+ current in pressure-overload heart failure. J Biol Chem. 2008 In Press.

144. Bryant SM, Shipsey SJ, Hart G. Regional differences in electrical and mechanical properties of myocytes from guinea-pig hearts with mild left ventricular hypertrophy. Cardiovasc Res Aug;1997 35(2):315-23. [PubMed: 9349394]

145. Kleiman RB, Houser SR. Calcium currents in normal and hypertrophied isolated feline ventricular myocytes. Am J Physiol Dec;1988 255(6 Pt 2):H1434-42. [PubMed: 2849320]

146. Ryder KO, Bryant SM, Hart G. Membrane current changes in left ventricular myocytes isolated from guinea pigs after abdominal aortic coarctation. Cardiovasc Res Jul;1993 27(7):1278-87. [PubMed: 8252589]

147. Yellen G. The moving parts of voltage-gated ion channels. Q Rev Biophys Aug;1998 31(3):239_ 95. [PubMed: 10384687]

148. Shirokov R, Levis R, Shirokova N, Rios E. Ca(2+)-dependent inactivation of cardiac L-type Ca2+ channels does not affect their voltage sensor. J Gen Physiol Dec;1993 102(6):1005-30. [PubMed: 8133239] 
149. Pelzer D, Pelzer S, McDonald TF. Properties and regulation of calcium channels in muscle cells. Rev Physiol Biochem Pharmacol 1990;114:107-207. [PubMed: 2155470]

150. Kubalova Z. Inactivation of L-type calcium channels in cardiomyocytes. Experimental and theoretical approaches. Gen Physiol Biophys Dec;2003 22(4):441-54. [PubMed: 15113117]

151. Piot C, Lemaire S, Albat B, Seguin J, Nargeot J, Richard S. High frequency-induced upregulation of human cardiac calcium currents. Circulation Jan 1;1996 93(1):120-8. [PubMed: 8616918]

152. Beuckelmann DJ, Erdmann E. Ca(2+)-currents and intracellular [Ca2+]i-transients in single ventricular myocytes isolated from terminally failing human myocardium. Basic Res Cardiol 1992;87(Suppl 1):235-43. [PubMed: 1497571]

153. Mewes T, Ravens U. L-type calcium currents of human myocytes from ventricle of non-failing and failing hearts and from atrium. J Mol Cell Cardiol Oct;1994 26(10):1307-20. [PubMed: 7869391]

154. Ouadid H, Albat B, Nargeot J. Calcium currents in diseased human cardiac cells. J Cardiovasc Pharmacol Feb;1995 25(2):282-91. [PubMed: 7752654]

155. Schroder F, Handrock R, Beuckelmann DJ, Hirt S, Hullin R, Priebe L, et al. Increased availability and open probability of single L-type calcium channels from failing compared with nonfailing human ventricle. Circulation Sep 8;1998 98(10):969-76. [PubMed: 9737516]

156. Rasmussen RP, Minobe W, Bristow MR. Calcium antagonist binding sites in failing and nonfailing human ventricular myocardium. Biochem Pharmacol Feb 15;1990 39(4):691-6. [PubMed: 2154992]

157. Schmidt U, Schwinger RH, Bohm S, Uberfuhr P, Kreuzer E, Reichart B, et al. Evidence for an interaction of halothane with the L-type $\mathrm{Ca} 2+$ channel in human myocardium. Anesthesiology Aug; 1993 79(2):332-9. [PubMed: 7688198]

158. Gruver EJ, Morgan JP, Stambler BS, Gwathmey JK. Uniformity of calcium channel number and isometric contraction in human right and left ventricular myocardium. Basic Res Cardiol Mar-Apr; 1994 89(2):139-48. [PubMed: 8074638]

159. Schwinger RH, Hoischen S, Reuter H, Hullin R. Regional expression and functional characterization of the L-type Ca2+-channel in myocardium from patients with end-stage heart failure and in nonfailing human hearts. J Mol Cell Cardiol Jan;1999 31(1):283-96. [PubMed: 10072735]

160. Takahashi T, Allen PD, Lacro RV, Marks AR, Dennis AR, Schoen FJ, et al. Expression of dihydropyridine receptor $(\mathrm{Ca} 2+$ channel $)$ and calsequestrin genes in the myocardium of patients with end-stage heart failure. J Clin Invest Sep;1992 90(3):927-35. [PubMed: 1326001]

161. Yang Y, Chen X, Margulies K, Jeevanandam V, Pollack P, Bailey BA, et al. L-type Ca2+ channel alpha 1c subunit isoform switching in failing human ventricular myocardium. J Mol Cell Cardiol Jun;2000 32(6):973-84. [PubMed: 10888251]

162. Studer R, Reinecke H, Bilger J, Eschenhagen T, Bohm M, Hasenfuss G, et al. Gene expression of the cardiac $\mathrm{Na}(+)-\mathrm{Ca} 2+$ exchanger in end-stage human heart failure. Circ Res Sep;1994 75(3):44353. [PubMed: 8062418]

163. Flesch M, Schwinger RH, Schiffer F, Frank K, Sudkamp M, Kuhn-Regnier F, et al. Evidence for functional relevance of an enhanced expression of the $\mathrm{Na}(+)-\mathrm{Ca} 2+$ exchanger in failing human myocardium. Circulation Sep 1;1996 94(5):992-1002. [PubMed: 8790037]

164. Reinecke H, Studer R, Vetter R, Holtz J, Drexler H. Cardiac Na+/Ca2+ exchange activity in patients with end-stage heart failure. Cardiovasc Res Jan;1996 31(1):48-54. [PubMed: 8849588]

165. Wang Z, Nolan B, Kutschke W, Hill JA. Na+-Ca2+ exchanger remodeling in pressure overload cardiac hypertrophy. J Biol Chem May 25;2001 276(21):17706-11. [PubMed: 11279089]

166. Schillinger W, Fiolet JW, Schlotthauer K, Hasenfuss G. Relevance of Na+-Ca2+ exchange in heart failure. Cardiovasc Res Mar 15;2003 57(4):921-33. [PubMed: 12650870]

167. Pogwizd SM, Qi M, Yuan W, Samarel AM, Bers DM. Upregulation of $\mathrm{Na}(+) / \mathrm{Ca}(2+)$ exchanger expression and function in an arrhythmogenic rabbit model of heart failure. Circ Res Nov 26;1999 85(11):1009-19. [PubMed: 10571531]

168. Pogwizd SM, Schlotthauer K, Li L, Yuan W, Bers DM. Arrhythmogenesis and contractile dysfunction in heart failure: Roles of sodium-calcium exchange, inward rectifier potassium current, and residual beta-adrenergic responsiveness. Circ Res Jun 8;2001 88(11):1159-67. [PubMed: 11397782] 
169. Reuter H, Pott C, Goldhaber JI, Henderson SA, Philipson KD, Schwinger RH. Na(+)--Ca2+ exchange in the regulation of cardiac excitation-contraction coupling. Cardiovasc Res Aug 1;2005 67(2):198-207. [PubMed: 15935336]

170. Diedrichs H, Frank K, Schneider CA, Burst V, Hagemeister J, Zobel C, et al. Increased functional importance of the $\mathrm{Na}, \mathrm{Ca}$-exchanger in contracting failing human myocardium but unchanged activity in isolated vesicles. Int Heart J Nov;2007 48(6):755-66. [PubMed: 18160767]

171. Schwinger RH, Wang J, Frank K, Muller-Ehmsen J, Brixius K, McDonough AA, et al. Reduced sodium pump alpha1, alpha3, and beta1-isoform protein levels and $\mathrm{Na}+\mathrm{K}+$-ATPase activity but unchanged $\mathrm{Na}+-\mathrm{Ca} 2+$ exchanger protein levels in human heart failure. Circulation Apr 27;1999 99 (16):2105-12. [PubMed: 10217649]

172. Reuter H, Henderson SA, Han T, Mottino GA, Frank JS, Ross RS, et al. Cardiac excitationcontraction coupling in the absence of $\mathrm{Na}(+)$ - Ca2+ exchange. Cell Calcium Jul;2003 34(1):1926. [PubMed: 12767889]

173. Dhalla NS, Dixon IM, Rupp H, Barwinsky J. Experimental congestive heart failure due to myocardial infarction: sarcolemmal receptors and cation transporters. Basic Res Cardiol 1991;86(Suppl 3):1323. [PubMed: 1664205]

174. Yao A, Su Z, Nonaka A, Zubair I, Spitzer KW, Bridge JH, et al. Abnormal myocyte Ca2+ homeostasis in rabbits with pacing-induced heart failure. Am J Physiol Oct;1998 275(4 Pt 2):H1441-8. [PubMed: 9746495]

175. Winslow RL, Rice J, Jafri S, Marban E, O'Rourke B. Mechanisms of altered excitation-contraction coupling in canine tachycardia-induced heart failure, II: model studies. Circ Res Mar 19;1999 84 (5):571-86. [PubMed: 10082479]

176. Janvier NC, Boyett MR. The role of Na-Ca exchange current in the cardiac action potential. Cardiovasc Res Jul;1996 32(1):69-84. [PubMed: 8776405]

177. Nagy ZA, Virag L, Toth A, Biliczki P, Acsai K, Banyasz T, et al. Selective inhibition of sodiumcalcium exchanger by SEA-0400 decreases early and delayed after depolarization in canine heart. Br J Pharmacol Dec;2004 143(7):827-31. [PubMed: 15504749]

178. Armoundas AA, Hobai IA, Tomaselli GF, Winslow RL, O'Rourke B. Role of sodium-calcium exchanger in modulating the action potential of ventricular myocytes from normal and failing hearts. Circ Res Jul 11;2003 93(1):46-53. [PubMed: 12805237]

179. Pogwizd SM, Sipido KR, Verdonck F, Bers DM. Intracellular Na in animal models of hypertrophy and heart failure: contractile function and arrhythmogenesis. Cardiovasc Res Mar 15;2003 57(4): 887-96. [PubMed: 12650867]

180. Sipido KR, Bito V, Antoons G, Volders PG, Vos MA. Na/Ca exchange and cardiac ventricular arrhythmias. Ann N Y Acad Sci Mar;2007 1099:339-48. [PubMed: 17446474]

181. Lab MJ. Monophasic action potentials and the detection and significance of mechanoelectric feedback in vivo. Prog Cardiovasc Dis Jul-Aug;1991 34(1):29-35. [PubMed: 2063011]

182. Taggart P. Mechano-electric feedback in the human heart. Cardiovasc Res Jul;1996 32(1):38-43. [PubMed: 8776401]

183. Lab MJ, Taggart P, Sachs F. Mechano-electric feedback. Cardiovasc Res Jul;1996 32(1):1-2. [PubMed: 8776397]

184. Franz MR, Cima R, Wang D, Profitt D, Kurz R. Electrophysiological effects of myocardial stretch and mechanical determinants of stretch-activated arrhythmias. Circulation Sep;1992 86(3):968-78. [PubMed: 1381296]

185. Nazir SA, Lab MJ. Mechanoelectric feedback and atrial arrhythmias. Cardiovasc Res Jul;1996 32 (1):52-61. [PubMed: 8776403]

186. Zeng T, Bett GC, Sachs F. Stretch-activated whole cell currents in adult rat cardiac myocytes. Am J Physiol Heart Circ Physiol Feb;2000 278(2):H548-57. [PubMed: 10666087]

187. Song YD, Yang XC, Liu TF, Gu ZW. Nonselective cation current in rabbit ventricular myocytes. Methods Find Exp Clin Pharmacol Jul-Aug;2005 27(6):377-83. [PubMed: 16179954]

188. Hu H, Sachs F. Mechanically activated currents in chick heart cells. J Membr Biol Dec;1996 154 (3):205-16. [PubMed: 8952950]

189. Sasaki N, Mitsuiye T, Noma A. Effects of mechanical stretch on membrane currents of single ventricular myocytes of guinea-pig heart. Jpn J Physiol 1992;42(6):957-70. [PubMed: 1297861] 
190. Taggart P, Lab M. Cardiac mechano-electric feedback and electrical restitution in humans. Prog Biophys Mol Biol Jun-Jul;2008 97(2-3):452-60. [PubMed: 18407323]

191. Nishimura S, Seo K, Nagasaki M, Hosoya Y, Yamashita H, Fujita H, et al. Responses of singleventricular myocytes to dynamic axial stretching. Prog Biophys Mol Biol Jun-Jul;2008 97(2-3): 282-97. [PubMed: 18471867]

192. Riemer TL, Sobie EA, Tung L. Stretch-induced changes in arrhythmogenesis and excitability in experimentally based heart cell models. Am J Physiol Aug;1998 275(2 Pt 2):H431-42. [PubMed: 9683430]

193. Wang Y, Joyner RW, Wagner MB, Cheng J, Lai D, Crawford BH. Stretch-activated channel activation promotes early afterdepolarizations in rat ventricular myocytes under oxidative stress. Am J Physiol Heart Circ Physiol May;2009 296(5):H1227-35. [PubMed: 19286952]

194. Fotopoulos GD, Mason MJ, Walker S, Jepson NS, Patel DJ, Mitchell AG, et al. Stabilisation of medically refractory ventricular arrhythmia by intra-aortic balloon counterpulsation. Heart Jul;1999 82(1):96-100. [PubMed: 10377318]

195. Guerrero PA, Schuessler RB, Davis LM, Beyer EC, Johnson CM, Yamada KA, et al. Slow ventricular conduction in mice heterozygous for a connexin43 null mutation. J Clin Invest Apr 15;1997 99(8):1991-8. [PubMed: 9109444]

196. Thomas SA, Schuessler RB, Berul CI, Beardslee MA, Beyer EC, Mendelsohn ME, et al. Disparate effects of deficient expression of connexin43 on atrial and ventricular conduction: evidence for chamber-specific molecular determinants of conduction. Circulation Feb 24;1998 97(7):686-91. [PubMed: 9495305]

197. Coppen SR, Dupont E, Rothery S, Severs NJ. Connexin 45 expression is preferentially associated with the ventricular conduction system in mouse and rat heart. Circ Res Feb 9;1998 82(2):232-43. [PubMed: 9468194]

198. Bukauskas FF, Elfgang C, Willecke K, Weingart R. Biophysical properties of gap junction channels formed by mouse connexin40 in induced pairs of transfected human HeLa cells. Biophys J Jun; 1995 68(6):2289-98. [PubMed: 7544165]

199. Gourdie RG, Severs NJ, Green CR, Rothery S, Germroth P, Thompson RP. The spatial distribution and relative abundance of gap-junctional connexin 40 and connexin 43 correlate to functional properties of components of the cardiac atrioventricular conduction system. J Cell Sci Aug;1993 105(Pt 4):985-91. [PubMed: 8227219]

200. Gros D, Jarry-Guichard T, Ten Velde I, de Maziere A, van Kempen MJ, Davoust J, et al. Restricted distribution of connexin40, a gap junctional protein, in mammalian heart. Circ Res May;1994 74 (5):839-51. [PubMed: 8156631]

201. Smith JH, Green CR, Peters NS, Rothery S, Severs NJ. Altered patterns of gap junction distribution in ischemic heart disease. An immunohistochemical study of human myocardium using laser scanning confocal microscopy. Am J Pathol Oct;1991 139(4):801-21. [PubMed: 1656760]

202. Peters NS, Coromilas J, Severs NJ, Wit AL. Disturbed connexin43 gap junction distribution correlates with the location of reentrant circuits in the epicardial border zone of healing canine infarcts that cause ventricular tachycardia. Circulation Feb 18;1997 95(4):988-96. [PubMed: 9054762]

203. Patel VB, Siddiq T, Sherwood R, Richardson PJ, Preedy VR. Effects of the dihydropyridine calcium channel blocker amlodipine on ventricular and atrial protein synthesis in an aortic constriction model of hypertension and, following chronic treatment, in the left ventricle of SHR rats. Int J Cardiol Feb;1997 58(3):241-55. [PubMed: 9076550]

204. Matsushita T, Oyamada M, Fujimoto K, Yasuda Y, Masuda S, Wada Y, et al. Remodeling of cellcell and cell-extracellular matrix interactions at the border zone of rat myocardial infarcts. Circ Res Nov 26;1999 85(11):1046-55. [PubMed: 10571536]

205. Uzzaman M, Honjo H, Takagishi Y, Emdad L, Magee AI, Severs NJ, et al. Remodeling of gap junctional coupling in hypertrophied right ventricles of rats with monocrotaline-induced pulmonary hypertension. Circ Res Apr 28;2000 86(8):871-8. [PubMed: 10785509]

206. Emdad L, Uzzaman M, Takagishi Y, Honjo H, Uchida T, Severs NJ, et al. Gap junction remodeling in hypertrophied left ventricles of aortic-banded rats: prevention by angiotensin II type 1 receptor blockade. J Mol Cell Cardiol Feb;2001 33(2):219-31. [PubMed: 11162128] 
207. Dupont E, Matsushita T, Kaba RA, Vozzi C, Coppen SR, Khan N, et al. Altered connexin expression in human congestive heart failure. J Mol Cell Cardiol Feb;2001 33(2):359-71. [PubMed: 11162139]

208. Ai X, Pogwizd SM. Connexin 43 downregulation and dephosphorylation in nonischemic heart failure is associated with enhanced colocalized protein phosphatase type 2A. Circ Res Jan 7;2005 96(1):54-63. [PubMed: 15576650]

209. Akar FG, Spragg DD, Tunin RS, Kass DA, Tomaselli GF. Mechanisms underlying conduction slowing and arrhythmogenesis in nonischemic dilated cardiomyopathy. Circ Res Oct 1;2004 95(7): 717-25. [PubMed: 15345654]

210. Poelzing S, Rosenbaum DS. Altered connexin43 expression produces arrhythmia substrate in heart failure. Am J Physiol Heart Circ Physiol Oct;2004 287(4):H1762-70. [PubMed: 15205174]

211. Liu F, Gutstein DE. The cardiac gap junction: a potential therapeutic target in the treatment of heart disease. Mt Sinai J Med Nov;2002 69(6):421-4. [PubMed: 12429963]

212. Chung CY, Bien H, Entcheva E. The role of cardiac tissue alignment in modulating electrical function. J Cardiovasc Electrophysiol Dec;2007 18(12):1323-9. [PubMed: 17916158]

213. Koller ML, Maier SK, Gelzer AR, Bauer WR, Meesmann M, Gilmour RF Jr. Altered dynamics of action potential restitution and alternans in humans with structural heart disease. Circulation Sep 13;2005 112(11):1542-8. [PubMed: 16157783]

214. Sukhareva M, Morrissette J, Coronado R. Mechanism of chloride-dependent release of Ca2+ in the sarcoplasmic reticulum of rabbit skeletal muscle. Biophys J Aug;1994 67(2):751-65. [PubMed: 7948689]

215. McPherson PS, Campbell KP. The ryanodine receptor/Ca2+ release channel. J Biol Chem Jul 5;1993 268(19):13765-8. [PubMed: 8390976]

216. Tarroni P, Rossi D, Conti A, Sorrentino V. Expression of the ryanodine receptor type 3 calcium release channel during development and differentiation of mammalian skeletal muscle cells. J Biol Chem Aug 8;1997 272(32):19808-13. [PubMed: 9242641]

217. Marx SO, Reiken S, Hisamatsu Y, Jayaraman T, Burkhoff D, Rosemblit N, et al. PKA phosphorylation dissociates FKBP12.6 from the calcium release channel (ryanodine receptor): defective regulation in failing hearts. Cell May 12;2000 101(4):365-76. [PubMed: 10830164]

218. Bultynck G, Vermassen E, Szlufcik K, De Smet P, Fissore RA, Callewaert G, et al. Calcineurin and intracellular Ca2+-release channels: regulation or association? Biochem Biophys Res Commun Nov 28;2003 311(4):1181-93. [PubMed: 14623304]

219. Nimer LR, Needleman DH, Hamilton SL, Krall J, Movsesian MA. Effect of ryanodine on sarcoplasmic reticulum $\mathrm{Ca} 2+$ accumulation in nonfailing and failing human myocardium. Circulation Nov 1;1995 92(9):2504-10. [PubMed: 7586351]

220. Meyer M, Schillinger W, Pieske B, Holubarsch C, Heilmann C, Posival H, et al. Alterations of sarcoplasmic reticulum proteins in failing human dilated cardiomyopathy. Circulation Aug 15;1995 92(4):778-84. [PubMed: 7641356]

221. Sainte Beuve C, Allen PD, Dambrin G, Rannou F, Marty I, Trouve P, et al. Cardiac calcium release channel (ryanodine receptor) in control and cardiomyopathic human hearts: mRNA and protein contents are differentially regulated. J Mol Cell Cardiol Apr;1997 29(4):1237-46. [PubMed: 9160875]

222. Go LO, Moschella MC, Watras J, Handa KK, Fyfe BS, Marks AR. Differential regulation of two types of intracellular calcium release channels during end-stage heart failure. J Clin Invest Feb;1995 95(2):888-94. [PubMed: 7860772]

223. Borlak J, Thum T. Hallmarks of ion channel gene expression in end-stage heart failure. FASEB J Sep;2003 17(12):1592-608. [PubMed: 12958166]

224. Zhang T, Maier LS, Dalton ND, Miyamoto S, Ross J Jr. Bers DM, et al. The deltaC isoform of CaMKII is activated in cardiac hypertrophy and induces dilated cardiomyopathy and heart failure. Circ Res May 2;2003 92(8):912-9. [PubMed: 12676814]

225. Bers DM. Cardiac ryanodine receptor phosphorylation: target sites and functional consequences. Biochem J May 15;2006 396(1):e1-3. [PubMed: 16626281]

226. Kohlhaas M, Zhang T, Seidler T, Zibrova D, Dybkova N, Steen A, et al. Increased sarcoplasmic reticulum calcium leak but unaltered contractility by acute CaMKII overexpression in isolated rabbit cardiac myocytes. Circ Res Feb 3;2006 98(2):235-44. [PubMed: 16373600] 
227. Ai X, Curran JW, Shannon TR, Bers DM, Pogwizd SM. Ca2+/calmodulin-dependent protein kinase modulates cardiac ryanodine receptor phosphorylation and sarcoplasmic reticulum $\mathrm{Ca} 2+$ leak in heart failure. Circ Res Dec 9;2005 97(12):1314-22. [PubMed: 16269653]

228. Curran J, Hinton MJ, Rios E, Bers DM, Shannon TR. Beta-adrenergic enhancement of sarcoplasmic reticulum calcium leak in cardiac myocytes is mediated by calcium/calmodulin-dependent protein kinase. Circ Res Feb 16;2007 100(3):391-8. [PubMed: 17234966]

229. Engelender S, De Meis L. Pharmacological differentiation between intracellular calcium pump isoforms. Mol Pharmacol Nov;1996 50(5):1243-52. [PubMed: 8913356]

230. Verboomen H, Wuytack F, De Smedt H, Himpens B, Casteels R. Functional difference between SERCA2a and SERCA2b Ca2+ pumps and their modulation by phospholamban. Biochem J Sep 1;1992 286(Pt 2):591-5. [PubMed: 1326945]

231. Koss KL, Kranias EG. Phospholamban: a prominent regulator of myocardial contractility. Circ Res Dec;1996 79(6):1059-63. [PubMed: 8943944]

232. Movsesian MA, Nishikawa M, Adelstein RS. Phosphorylation of phospholamban by calciumactivated, phospholipid-dependent protein kinase. Stimulation of cardiac sarcoplasmic reticulum calcium uptake. J Biol Chem Jul 10;1984 259(13):8029-32. [PubMed: 6234308]

233. Simmerman HK, Collins JH, Theibert JL, Wegener AD, Jones LR. Sequence analysis of phospholamban. Identification of phosphorylation sites and two major structural domains. J Biol Chem Oct 5;1986 261(28):13333-41. [PubMed: 3759968]

234. Wegener AD, Simmerman HK, Lindemann JP, Jones LR. Phospholamban phosphorylation in intact ventricles. Phosphorylation of serine 16 and threonine 17 in response to beta-adrenergic stimulation. J Biol Chem Jul 5;1989 264(19):11468-74. [PubMed: 2544595]

235. Talosi L, Edes I, Kranias EG. Intracellular mechanisms mediating reversal of beta-adrenergic stimulation in intact beating hearts. Am J Physiol Mar;1993 264(3 Pt 2):H791-7. [PubMed: 8384422]

236. Kranias EG. Regulation of Ca2+ transport by cyclic 3',5'-AMP-dependent and calcium-calmodulindependent phosphorylation of cardiac sarcoplasmic reticulum. Biochim Biophys Acta Feb 21;1985 844(2):193-9. [PubMed: 2982423]

237. Tada M, Inui M, Yamada M, Kadoma M, Kuzuya T, Abe H, et al. Effects of phospholamban phosphorylation catalyzed by adenosine 3':5'-monophosphate- and calmodulin-dependent protein kinases on calcium transport ATPase of cardiac sarcoplasmic reticulum. J Mol Cell Cardiol May; 1983 15(5):335-46. [PubMed: 6310131]

238. Davis BA, Schwartz A, Samaha FJ, Kranias EG. Regulation of cardiac sarcoplasmic reticulum calcium transport by calcium-calmodulin-dependent phosphorylation. J Biol Chem Nov 25;1983 258(22):13587-91. [PubMed: 6227613]

239. Jackson WA, Colyer J. Translation of Ser16 and Thr17 phosphorylation of phospholamban into Ca 2+-pump stimulation. Biochem J May 15;1996 316(Pt 1):201-7. [PubMed: 8645206]

240. Le Peuch CJ, Haiech J, Demaille JG. Concerted regulation of cardiac sarcoplasmic reticulum calcium transport by cyclic adenosine monophosphate dependent and calcium--calmodulin-dependent phosphorylations. Biochemistry Nov 13;1979 18(23):5150-7. [PubMed: 227448]

241. Raeymaekers L, Hofmann F, Casteels R. Cyclic GMP-dependent protein kinase phosphorylates phospholamban in isolated sarcoplasmic reticulum from cardiac and smooth muscle. Biochem $\mathbf{J}$ May 15;1988 252(1):269-73. [PubMed: 2844148]

242. Colyer J, Wang JH. Dependence of cardiac sarcoplasmic reticulum calcium pump activity on the phosphorylation status of phospholamban. J Biol Chem Sep 15;1991 266(26):17486-93. [PubMed: 1832673]

243. Chu G, Lester JW, Young KB, Luo W, Zhai J, Kranias EG. A single site (Ser16) phosphorylation in phospholamban is sufficient in mediating its maximal cardiac responses to beta -agonists. J Biol Chem Dec 8;2000 275(49):38938-43. [PubMed: 10988285]

244. MacDougall LK, Jones LR, Cohen P. Identification of the major protein phosphatases in mammalian cardiac muscle which dephosphorylate phospholamban. Eur J Biochem Mar 28;1991 196(3):72534. [PubMed: 1849481] 
245. Dash R, Frank KF, Carr AN, Moravec CS, Kranias EG. Gender influences on sarcoplasmic reticulum Ca2+-handling in failing human myocardium. J Mol Cell Cardiol Jul;2001 33(7):1345-53. [PubMed: 11437540]

246. Hasenfuss G, Reinecke H, Studer R, Meyer M, Pieske B, Holtz J, et al. Relation between myocardial function and expression of sarcoplasmic reticulum $\mathrm{Ca}(2+)$-ATPase in failing and nonfailing human myocardium. Circ Res Sep;1994 75(3):434-42. [PubMed: 8062417]

247. Schwinger RH, Bohm M, Schmidt U, Karczewski P, Bavendiek U, Flesch M, et al. Unchanged protein levels of SERCA II and phospholamban but reduced Ca2+ uptake and $\mathrm{Ca}(2+)$-ATPase activity of cardiac sarcoplasmic reticulum from dilated cardiomyopathy patients compared with patients with nonfailing hearts. Circulation Dec 1;1995 92(11):3220-8. [PubMed: 7586307]

248. Frank K, Bolck B, Bavendiek U, Schwinger RH. Frequency dependent force generation correlates with sarcoplasmic calcium ATPase activity in human myocardium. Basic Res Cardiol Oct;1998 93 (5):405-11. [PubMed: 9833153]

249. Movsesian MA, Karimi M, Green K, Jones LR. Ca(2+)-transporting ATPase, phospholamban, and calsequestrin levels in nonfailing and failing human myocardium. Circulation Aug;1994 90(2):6537. [PubMed: 8044934]

250. MacLennan DH, Kranias EG. Phospholamban: a crucial regulator of cardiac contractility. Nat Rev Mol Cell Biol Jul;2003 4(7):566-77. [PubMed: 12838339]

251. Heineke J, Molkentin JD. Regulation of cardiac hypertrophy by intracellular signalling pathways. Nat Rev Mol Cell Biol Aug;2006 7(8):589-600. [PubMed: 16936699]

252. Nakayama H, Chen X, Baines CP, Klevitsky R, Zhang X, Zhang H, et al. Ca2+- and mitochondrialdependent cardiomyocyte necrosis as a primary mediator of heart failure. J Clin Invest Sep;2007 117(9):2431-44. [PubMed: 17694179]

253. Nakayama H, Bodi I, Correll RN, Chen X, Lorenz J, Houser SR, et al. alpha1G-dependent T-type $\mathrm{Ca} 2+$ current antagonizes cardiac hypertrophy through a NOS3-dependent mechanism in mice. $\mathrm{J}$ Clin Invest Dec;2009 119(12):3787-96. [PubMed: 19920353]

254. Wickenden AD, Lee P, Sah R, Huang Q, Fishman GI, Backx PH. Targeted expression of a dominantnegative $\mathrm{K}(\mathrm{v}) 4.2 \mathrm{~K}(+)$ channel subunit in the mouse heart. Circ Res Nov 26;1999 85(11):1067-76. [PubMed: 10571538]

255. Kassiri Z, Zobel C, Nguyen TT, Molkentin JD, Backx PH. Reduction of I(to) causes hypertrophy in neonatal rat ventricular myocytes. Circ Res Mar 22;2002 90(5):578-85. [PubMed: 11909822]

256. Wang Y, Cheng J, Tandan S, Jiang M, McCloskey DT, Hill JA. Transient-outward K+ channel inhibition facilitates L-type Ca2+ current in heart. J Cardiovasc Electrophysiol Mar;2006 17(3): 298-304. [PubMed: 16643405]

257. Go AS, Hylek EM, Phillips KA, Chang Y, Henault LE, Selby JV, et al. Prevalence of diagnosed atrial fibrillation in adults: national implications for rhythm management and stroke prevention: the AnTicoagulation and Risk Factors in Atrial Fibrillation (ATRIA) Study. JAMA May 9;2001 285 (18):2370-5. [PubMed: 11343485] 


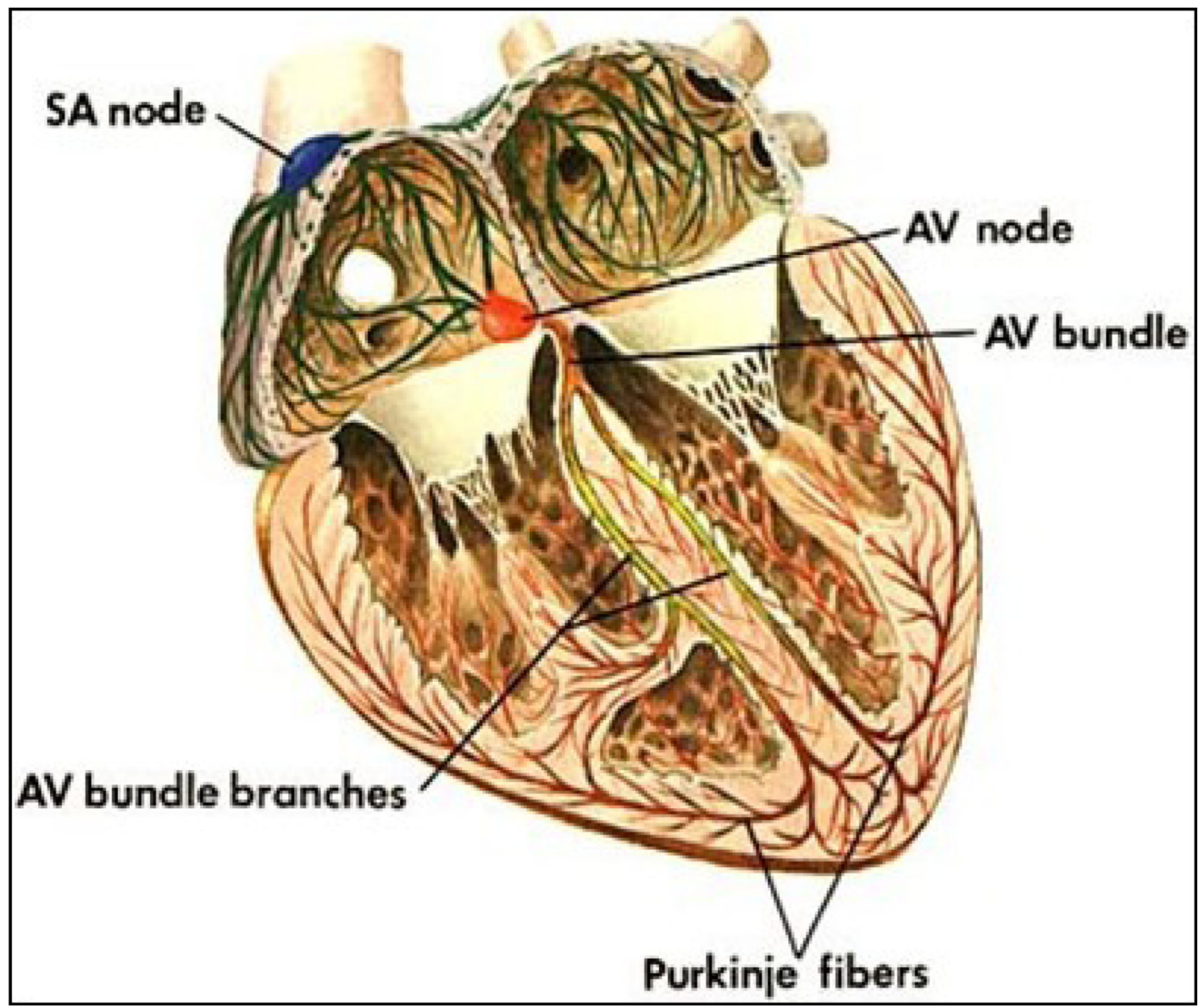

Figure 1. Cardiac conduction system

(C) Carolina Biological Supply Company, Used with permission) 

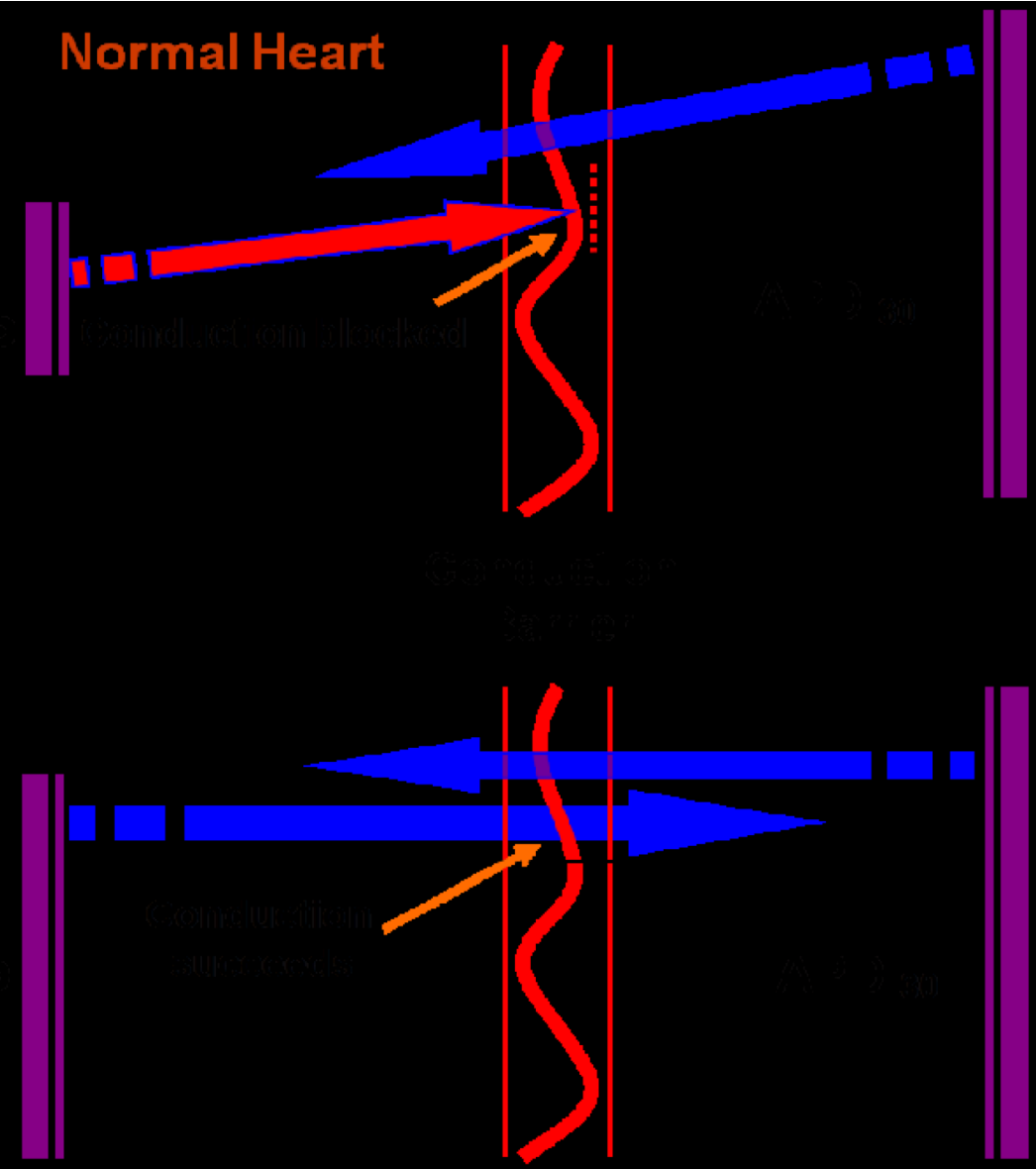

\section{Failing Heart}

Figure 2. Anisotropic conduction between subendocardial and subepicardial layers of $\mathrm{LV}$

In normal heart, impulse conduction is favored in the physiological direction of subendocardium (SEN) to subepicardium (SEP) and relatively disfavored from SEP to SEN. Electrical remodeling in heart failure, including AP prolongation and a diminished transmural gradient of APD30, abolishes directionally preferential conduction. 